\title{
EXPECTATIONS-DRIVEN CYCLES IN THE HOUSING MARKET
}

tuisa tambertini, Caterina Mendicino.

and Maria Teresa Punzi

Documentos de Trabajo.

N. 1021

\section{baneodespaña}

\author{
Eurosistema
}


EXPECTATIONS-DRIVEN CYCLES IN THE HOUSING MARKET 
EXPECTATIONS-DRIVEN CYCLES IN THE HOUSING MARKET ${ }^{*}$

\author{
Luisa Lambertini ${ }^{(*)}$ \\ COLLEGE OF MANAGEMENT
}

Caterina Mendicino ${ }^{(* *)}$ and Maria Teresa Punzi ${ }^{(* * *)}$

BANCO DE PORTUGAL 
The Working Paper Series seeks to disseminate original research in economics and finance. All papers have been anonymously refereed. By publishing these papers, the Banco de España aims to contribute to economic analysis and, in particular, to knowledge of the Spanish economy and its international environment.

The opinions and analyses in the Working Paper Series are the responsibility of the authors and, therefore, do not necessarily coincide with those of the Banco de España or the Eurosystem.

The Banco de España disseminates its main reports and most of its publications via the INTERNET at the following website: http://www.bde.es.

Reproduction for educational and non-commercial purposes is permitted provided that the source is acknowledged.

() BANCO DE ESPAÑA, Madrid, 2010

ISSN: 0213-2710 (print)

ISSN: 1579-8666 (on line)

Depósito legal: M. 30228-2010

Unidad de Publicaciones, Banco de España 


\section{Abstract}

This paper analyzes housing market boom-bust cycles driven by changes in households' expectations. We explore the role of expectations not only on productivity but on several other shocks that originate in the housing market, the credit market and the conduct of monetary policy. We find that, in the presence of nominal rigidities, expectations on both the conduct of monetary policy and future productivity can generate housing market boom-bust cycles in accordance with the empirical findings. Moreover, expectations of either a future reduction in the policy rate or a temporary increase in the central bank's inflation target that are not fulfilled generate a macroeconomic recession. Increased access to credit generates a boom-bust cycle in most variables only if it is expected to be reversed in the near future.

Keywords: boom-bust cycles, credit frictions, housing market.

JEL classification: E32, E44, E52. 


\section{Introduction}

Boom-bust cycles in asset prices and economic activity are a central issue in policy and academic debates. Particular attention has been given to the behavior of housing prices and housing investment. We document that, over the last three decades, housing prices boom-bust cycles in the United States have been characterized by co-movement in GDP, consumption, investment, hours worked, real wages, housing investment. Moreover, housing price peaks are often followed by macroeconomic recessions.

This paper suggests a mechanism for modeling housing-market boom-bust cycles in accordance with the empirical pattern. Modeling endogenous boom-bust cycles in macroeconomics is a major challenge. Our explanation builds on a "news shock" mechanism where public signals of future fundamentals cause business cycle fluctuations through changes in household expectations. Booms are generated by public signals; busts follow if the signals are not realized ex-post. To this purpose, we extend the model of the housing market developed by Iacoviello and Neri (2009) to include expectations of future macroeconomic developments. We rely on their estimated model since it is successful in explaining both the trend and short-run fluctuations in real housing prices and investment over the last four decades in the United States.

This paper provides several insightful results. First, we show that in the presence of nominal price and wage rigidities, expectations on future productivity generate business cycle fluctuations and boom-bust cycle dynamics in the housing market. Since Beautry and Portier (2004, 2007) a growing strand of the business cycle literature has investigated the role of changes in expectations or news about the future state of productivity as a source of business cycle fluctuations. Changes in expectations may prove to be an important mechanism in creating business cycle fluctuations if they generate pro-cyclical movements in consumption, hours and investment. However, as already shown by Beautry and Portier $(2004,2007)$, a standard one-sector optimal growth model is unable to generate boom-bust cycles in response to news due to the wealth effect generated by expectations of improved future macroeconomic conditions that make consumption increase and hours worked fall at the time of the signal. Christiano, Ilut, Motto, and Rostagno (2008) show that for the price of capital to be positively correlated with all other aggregate variables, an inflation targeting central bank and nominal wages stickier than prices are needed. Differently from previous studies we aim at reproducing empirically plausible boom-bust cycles in the housing market. We show that nominal rigidities, both in wages and prices are key to generate boom-bust cycle dynamics also in a model of the housing and credit market that features standard preferences and production functions. 
Second, our paper analyzes whether not only news about productivity but also news on other sources of macroeconomic fluctuations, such as housing demand and monetary policy, are able to generate expectations-driven cycles in the housing market. We show that a necessary condition for a boom-bust cycle is that agents expect a future increase in housing prices, which fuels current housing demand and lifts housing prices immediately. Thus, the increase in housing prices is coupled with an endogenous increase in household indebtedness. Accordingly, changes in expectations about future productivity, investment costs, housing supply, inflation, the policy rate and the central bank's target can generate housing-market boom-bust cycles characterized by co-movement in GDP, consumption, investment, hours and real wages.

Third, expectations of future expansionary monetary policy that are not met, both regarding the policy rate and the central bank's inflation target, are likely to cause a boom-bust cycle and a macroeconomic recession. Thus, a high degree of transparency in monetary policy reduces uncertainty about future monetary policy actions and thereby the occurrence of cycles.

Forth, we find that expectations of a future increase in housing demand fail to generate boombust cycles in the housing market. According to Iacoviello and Neri (2009) housing demand shocks explain one-quarter of fluctuations in housing prices and housing investment in the United States over the last four decades. However, we document that expectations of a future increase in housing demand lead to a housing price boom but fail to generate co-movement between business investment and all other aggregate variables.

Last, we analyze the effects of current and anticipated exogenous changes in credit conditions. According to our findings, changes in households' expectations about future macroeconomic developments lead to an increase in both housing prices and household indebtedness. However, expectations of future changes in the access to credit do not generate co-movement between business investment and GDP. In contrast, a current unanticipated increase in the access to credit raises on impact house prices and all other macroeconomic variables but fails to generate hump-shaped dynamics. We document that an exogenous improvement in the access to credit generates boom-bust cycle dynamics in aggregate variables only if the current situation in the credit market is expected to be reversed in the near future.

It is important to stress that the goal of this paper is not to explain exactly what happened to a specific country, but to draw qualitative conclusions on the plausibility of changes in expectations as a mechanism to generate boom-bust cycles in the housing market.

The rest of the paper is organized as follows. Section 2 characterizes the average behavior of several macroeconomic variables during four boom-bust episodes in the U.S. housing market in the 
last four decades. Section 3 describes the model. Section 4 investigate the occurrence of boom-bust cycles in the housing market as a consequence of expectations of higher future productivity. Section 5 explores the role of expectations on future developments in the housing market, in the conduct of monetary policy and in the credit market in generating boom-bust cycles and Section 6 concludes.

\section{Stylized Facts about Housing Boom-Bust Episodes}

Figure 1 shows a number of macroeconomic variables in the United States over the period 1965:1 to 2009:2. These variables are: Consumption, GDP, residential investment, business investment, home mortgage liabilities, house prices, hours worked and wages in the consumption sector, hours worked and wages in the housing sector, inflation and the nominal interest rate. Appendix A describes the data in detail. Aggregate variables are log-transformed, real, per capita with base in 1965:1. Real house prices in the United States trend upward over the sample period. From 1965:1 to 2009:2, real house prices increased by more than $66 \%$. According to Iacoviello and Neri (2009), the positive trend in real house prices reflects faster productivity in the consumer-good sector relative to the construction sector.

Real house prices also display a number of boom-bust episodes, namely periods of faster-thantrend growth followed by sharp reversals. We define a peak as the centered maximum in real house prices in a twenty-one-quarters window, excluding end points. Using this definition, we identify four peaks in real house prices in the United States: 1973:3; 1979:4; 1989:2; 2006:2. ${ }^{1}$ The vertical lines in Figure 1 indicate the peak dates. ${ }^{2}$ Our definition of peak is robust to de-trending, either with a linear trend or with an Hodrick-Prescott filter. ${ }^{3}$

Interestingly, real house prices peaks are followed by macroeconomic recessions. The grey shaded areas in Figure 1 indicate recession dates according to the National Bureau of Economic Research. ${ }^{4}$

\footnotetext{
${ }^{1}$ See Appendix B.

${ }^{2} \mathrm{~A}$ more stringent definition would require the peak to be the high of a longer centered window. For example, if we require the window to be twenty-five quarters, as in Ahearne et al. (2005), the 1973:3 high in real house prices would fail to be a peak. In general, upward trending house prices make it difficult to identify peaks in long, centered windows because prices do not fall all the way to the levels they had at the beginning of the boom. On the other hand, a shorter centered window of seventeen quarters would deliver an additional peak in 1969:4.

${ }^{3}$ Using the H-P filter and the twenty-one quarters definition of window would deliver two additional peaks in 1994:1 and 1999:2, the same peaks in 1973:3, 1979:4 and 1989:2, and it would put the most recent peak in 2007:1.

${ }^{4}$ At the time the paper was written, the National Bureau of Economic Research had dated the beginning of the recession in 2007:4 but not its end. Figure 7 assumes that the recession was not over yet as of the end of boom-bust window in 2008:4.
} 
Every housing peak as defined above has been followed by an economic downturn. Even the housing price high of 1969:4, which does not qualify as a peak according to our definition because real house prices rebound too quickly, is followed by a recession.

We are interested in characterizing the behavior of our macroeconomic variables during these four boom-bust episodes. First we consider the average behavior of our macroeconomic variables over the four peak episodes. Figure 2 shows the average behavior of these series in the twenty-one quarter window around a peak date. The vertical line indicates the peak in real house prices.

On average real house prices are pro-cyclical during boom-bust episodes. In fact, real house prices peak when real GDP reaches a maximum. Figures 4 to 7 illustrate the behavior of the macroeconomic variables of interest in each peak episode and we discuss the differences among peak episodes in Appendix B. Real personal consumption also increases during the boom in real house prices and peaks around the same time as the peak in real GDP and house prices.

Real private residential fixed investment reaches its maximum before the peak in house prices and falls rapidly afterward. On the other hand, real private nonresidential fixed investment raises during the boom period, peaks after the peak in housing prices and falls afterward. Hours worked follow closely the dynamics of real house prices, both in the construction and in the consumptiongood sector. Hours rise during the boom phase and fall during the bust one.

On average real loans grow during the boom phase and peak several quarters after the peak in housing prices. Inspection of the four peak episodes reveals that real loans typically peak at the beginning of the recession that follows the bust in housing prices. In the 1973:3 and 1979:4 episodes real GDP and real loans peak immediately after housing prices; in the 2006:2 real GDP and real loans peak only some quarters after housing prices. The 1989:2 housing peak is an exception, as real loans continued to grow despite a fall in housing prices. ${ }^{5}$ The evidence that real loans grow during the boom phase and fall during the bust phase of housing prices is in line with the findings in Kannan, Rabanal and Scott (2009), who consider several countries and find evidence of higherthan-normal growth rates of credit relative to GDP in the run-ups to house price busts since 1985. They also find large deteriorations in current account balances and higher-than-normal ratios of investment to GDP after 1985 but not before it.

The interest rate is the three months Treasury bill interest rate. It increases throughout the boom period, peaks around the time of or just after the peak in house prices, and then it falls rapidly. The empirical evidence therefore lends support to the hypothesis that housing price booms are accompanied by low interest rates.

\footnotetext{
${ }^{5}$ See Appendix B for detailed comments.
} 
Inflation follows real house prices and other macroeconomic variables with some lags. On average, inflation increases before the peak in house prices, reaches a maximum after the peak in house prices and then falls. Real wages are also pro-cyclical during boom-bust episodes. Real wages in the consumption-good sector rise in the boom and fall in the bust phase. Real wages in the construction sector have a similar pattern with a couple of differences: They peak before real house prices (and real wages in the consumption-good sector) and they fall much more rapidly after that.

Next we transform our variables in deviations from the Hodrick-Prescott filter and then calculate the average over the four housing-peak episodes. This allows us to see if housing boom-bust episodes are accompanied by below- or above-trend behavior of some variables. Figure 3 shows the data. A number of observations are in order. Real house prices, real GDP, private consumption and investment, both residential and nonresidential, and real loans fall below trend at the end of the bust phase. Models featuring unanticipated shocks that eventually die away cannot reproduce this feature of the data. The nominal interest rate is well below trend at the beginning of the boom phase, consistent with the evidence in Figure 2. Real wages start at or above trend, the reach a maximum before the peak in real house prices and then fall well below trend.

Table 1 displays the correlation of our Hodrick-Prescott filtered variables with real house prices and the standard deviation. The first column reports the statistics over the entire sample, 1965:1 to 2009:2; the second column displays the same statistics over the four twenty-one quarter windows centered around the peaks identified earlier. GDP, consumption, business investment, real loans, hours and real wages become more positively correlated, or maintain the same correlation, with real house prices during boom-bust episodes. On the other hand, the nominal interest rate and inflation are less correlated with real house prices during boom-bust episodes. Once again, this evidence lends support to the hypothesis that housing booms were accompanied by low inflation and interest rates. All variables except business investment are more volatile during peak episodes. The increase in volatility is substantial for real wages, inflation, residential investment, the interest rate and consumption.

\section{The Model}

We adopt the framework developed by Iacoviello and Neri (2009). The model's parameters are set equal to the mean of the posterior distribution estimated by Iacoviello and Neri (2009) for the U.S. economy. For completeness we report the main features of the model in the following. 


\subsection{Households}

The economy is populated by two types of households: the Saver and the Borrower. They both work in the good- and housing-sector of production, consume and accumulate housing. They differ in their discount factors, $\left(\beta\right.$ and $\left.\beta^{\prime}\right)$. Borrowers (denoted by ') feature a relatively lower subjective discount factor that in equilibrium generates an incentive to anticipate future consumption to the current period through borrowing. Hence, the ex-ante heterogeneity induces credit flows between the two types of agents. This modeling feature has been introduced in macro models by Kiyotaki and Moore (1997) and extended by Iacoviello (2005) to a business cycle framework with housing investment.

The Saver maximizes the utility function with respect to :

$$
U_{t}=E_{t} \sum_{t=0}^{\infty}\left(\beta G_{C}\right)^{t}\left[\Gamma_{c} \ln \left(c_{t}-\varepsilon c_{t-1}\right)+j_{t} \ln h_{t}-\frac{\tau}{1+\eta}\left(n_{c, t}^{1+\xi}+n_{h, t}^{1+\xi}\right)^{\frac{1+\eta}{1+\xi}}\right]
$$

subject to:

$$
\begin{gathered}
c_{t}+q_{t}\left(h_{t}-\left(1-\delta_{h}\right) h_{t-1}\right)+\left[\frac{k_{c, t}}{A_{k, t}}-\left(\frac{1-\delta_{k}}{A_{k, t}}+R_{c, t} z_{c, t}\right) k_{c t-1}\right]+\phi_{c, t}+\left[k_{h, t}\left(1-\delta_{k}+R_{h, t} z_{h, t}\right) k_{h t-1}\right]+ \\
\phi_{h, t}+k_{b, t}+p_{l, t} l_{t}-b_{t}+\frac{R_{t-1} b_{t-1}}{\pi_{t}} \leq \frac{w_{c, t} n_{c, t}}{X_{w c, t}}+\frac{w_{h, t} n_{h, t}}{X_{w h, t}}+p_{b, t} k_{b, t}+\left(p_{l, t}+R_{l, t}\right) l_{t-1}+D_{t},
\end{gathered}
$$

where $c, h, n_{c}$ and $n_{h}$ are consumption, housing services, hours worked in the good-sector and in the construction-sector, respectively. The parameter $\xi$ defines the degree of substitution between the two sectors in terms of hours worked. ${ }^{6} j_{t}$ determines the relative weight in utility of housing services, $R_{t}$ is the lending interest rate, $\delta_{c}$ and $\delta_{h}$ represent the depreciation rate for capital and housing stock, respectively. $l_{t}$ is the land priced at $p_{l, t}$ and $q_{t}$ is the price of houses, all relative to the CPI. $z_{c, t}$ and $z_{h, t}$ are the capital utilization rates of transforming potential capital into effective capital in the two sectors. $D_{t}$ are lump-sum profits paid to households. The term $A_{k, t}$ is investmentspecific technology that captures the marginal cost of producing consumption-good-sector specific capital. ${ }^{7} G_{C}, G_{I K_{c}}$ and $G_{I K_{h}}$ are the trend growth rates of real consumption and capital used in the two sectors of production. $\Gamma_{c}$ and $\Gamma_{c}^{\prime}$ represent scaling factors of the marginal utilities of

${ }^{6}$ For a value of $\xi$ close to zero, hours worked in the two sectors are close to perfect substitutes, which means that the worker would devote most of the time to the sector that pays the highest wage. Positive values of $\xi$ imply, instead, that hours worked are far from perfect substitutes, thus the worker is less willing to diversify her working hours across sectors even in the presence of a wage differential (see Horvath (2000) for details).

${ }^{7} \phi_{c, t}=\frac{\phi_{k c}}{2 G_{I K_{c}}}\left(\frac{k_{c, t}}{k_{c, t-1}}-G_{I K_{c}}\right)^{2} \frac{k_{c, t-1}}{\left(1+\gamma_{A K}\right)^{t}}$ is the good-sector capital adjustment cost, and $\phi_{h, t}=\frac{\phi_{k h}}{2 G_{I K h}}\left(\frac{k_{h, t}}{k_{h, t-1}}-\right.$ 
consumption. Wages are set in a monopolistic way and can be adjusted subject to a Calvo scheme with probability $1-\theta_{w}$ every period. $X_{w c, t}$ and $X_{w h, t}$ are markups on the wages paid in the two sectors. Both households set wages in a monopolistic way.

The Borrower maximizes the utility function:

$$
U_{t}=E_{t} \sum_{t=0}^{\infty}\left(\beta^{\prime} G_{C}\right)^{t}\left[\Gamma_{c}^{\prime} \ln \left(c_{t}^{\prime}-\varepsilon^{\prime} c_{t-1}^{\prime}\right)+j_{t} \ln h_{t}^{\prime}-\frac{\tau}{1+\eta^{\prime}}\left(\left(n_{c, t}^{\prime}\right)^{1+\xi^{\prime}}+\left(n_{h, t}^{\prime}\right)^{1+\xi^{\prime}}\right)^{\frac{1+\eta^{\prime}}{1+\xi^{\prime}}}\right]
$$

subject to:

$$
c_{t}^{\prime}+q_{t}\left[h_{t}^{\prime}-\left(1-\delta_{h}\right) h_{t-1}^{\prime}\right]-b_{t}^{\prime} \leq \frac{w_{c, t}^{\prime} n_{c, t}^{\prime}}{X_{w c, t}^{\prime}}+\frac{w_{h, t}^{\prime} n_{h, t}^{\prime}}{X_{w h, t}^{\prime}}+D_{t}^{\prime}-\frac{R_{t-1} b_{t-1}^{\prime}}{\pi_{t}}
$$

and

$$
b_{t}^{\prime} \leq m_{t} E_{t}\left(\frac{q_{t+1} h_{t}^{\prime} \pi_{t+1}}{R_{t}}\right) .
$$

$\beta^{\prime} \in(0, \beta)$ captures the Borrower's relative impatience.

Limits on borrowing are introduced through the assumption that households cannot borrow more than a fraction of the next-period value of the housing stock. The fraction $m$, referred to as the equity requirement or loan-to-value ratio, should not exceed one and is treated as exogenous to the model. It can be interpreted as the creditor's overall judicial costs in case of debtor default and represents the degree of credit frictions in the economy. The borrowing constraint is consistent with standard lending criteria used in the mortgage and consumer loan markets. We explore the effects of temporary deviations from the established degree of credit market access by assuming that $m_{t}$ is stochastic. We refer to this as a loan-to-value ratio shock.

\section{$3.2 \quad$ Firms}

Final good producing firms produce non-durable goods $(\mathrm{Y})$ and new houses (IH). Both sectors face Cobb-Douglas production functions. The housing sector uses capital, $k$, land, $l$, and labor supplied by the Savers, $n$, and the Borrowers, $n^{\prime}$, as inputs of production:

$$
I H_{t}=\left(A_{h, t}\left(n_{h, t}^{\alpha}+n_{h, t}^{\prime} 1-\alpha\right)\right)^{1-\mu_{h-\mu_{b}-\mu_{l}}}\left(z_{h, t} k_{h, t-1}\right)^{\mu_{h}} k_{b}^{\mu_{b}} l_{t-1}^{\mu_{l}} .
$$

$\left.G_{I K_{h}}\right)^{2} k_{h, t-1}$ is the housing-sector capital adjustment cost; $\gamma_{A K}$ represents the net growth rate of technology in business capital, $\phi_{k c}$ and $\phi_{k h}$ indicate the coefficients for adjustment cost (i.e., the relative prices of installing the existing capital) for capital used in the consumption sector and housing sector respectively. 
The non-housing sector produces consumption and business capital using labor and capital:

$$
Y_{t}=\left(A_{c, t}\left(n_{c, t}^{\alpha}+n_{c, t}^{\prime} 1-\alpha\right)\right)^{1-\mu_{c}}\left(z_{c, t} k_{c, t-1}\right)^{\mu_{c}}
$$

where $A_{h, t}$ and $A_{c, t}$ are the productivity shocks to the housing- and good-sector, respectively. Firms pay the wages to the households and pay back the rented capital to the Savers.

The intermediate good-sector is populated by a continuum of monopolistically competitive firms owned by the Savers. Prices can be adjusted by each producer with probability $1-\theta_{\pi}$ every period, following a Calvo-setting. Monopolistic competition occurs at the retail level, leading to the following forward-looking Philips curve:

$$
\ln \pi_{t}-\iota_{\pi} \ln \pi_{t-1}=\beta G_{C}\left(E_{t} \ln \pi_{t+1}-\iota_{\pi} \ln \pi_{t}\right)-\epsilon_{\pi} \ln \left(X_{t} / X\right)+u_{p, t}
$$

where $\epsilon_{\pi}=\frac{\left(1-\theta_{\pi}\right)\left(1-\beta \theta_{\pi}\right)}{\theta_{\pi}}, X_{t}$ represents the price markup and $u_{p, t}$ is a cost-push shock. In contrast, housing prices are assumed to be flexible.

\subsection{Monetary Policy Rule}

We assume that the central bank follows a Taylor-type rule as estimated by Iacoviello and Neri (2009):

$$
R_{t}=R_{t-1}^{r_{R}} \pi_{t}^{\left(1-r_{R}\right) r_{\pi}}\left(\frac{G D P_{t}}{G_{C} G D P_{t-1}}\right)^{\left(1-r_{R}\right) r_{Y}} r r^{\left(1-r_{R}\right)} \frac{u_{R, t}}{A_{s, t}}
$$

where $r r$ is the steady-state real interest rate and $u_{R, t}$ is a monetary policy shock. The central bank's target is assumed to be time varying and subject to a persistent shock, $s_{t}$, as in Smets and Wouters (2003). Following Iacoviello and Neri (2009), GDP is defined as the sum of consumption and investment at constant prices. Thus

$$
G D P_{t}=C_{t}+I K_{t}+q I H_{t}
$$

where $q$ is real housing prices along the balanced growth path.

\subsection{News Shocks}

The model assumes heterogeneous deterministic trends in productivity in the consumption $\left(A_{c, t}\right)$, investment $\left(A_{k, t}\right)$, and housing sector $\left(A_{h, t}\right)$ such that

$$
\ln \left(A_{z, t}\right)=t \ln \left(1+\gamma_{A z}\right)+\ln \left(Z_{z, t}\right)
$$


where $\gamma_{A z}$ are the net growth rates of technology in each sector, and

$$
\ln \left(Z_{z, t}\right)=\rho_{A z} A \ln \left(Z_{z, t-1}\right)+u_{z, t}
$$

where $u_{z, t}$ is the innovation and $z=\{c, k, h\}$. The inflation $\operatorname{target}\left(A_{s, t}\right)$, loan-to-value ratio $(m)$ and the preference $\left(j_{t}\right)$ shocks are assumed to follow an $A R(1)$ process. ${ }^{8}$ The cost-push shock $\left(u_{p, t}\right)$ and the shock to the policy rule $\left(u_{R, t}\right)$ are assumed to be i.i.d.To introduce expectations of future macroeconomic developments we follow Christiano et al. (2008) in assuming that the error term of each shock consists of an unanticipated component, $\varepsilon_{z, t}$, and an anticipated change $n$ quarters in advance, $\varepsilon_{z, t-n}$,

$$
u_{z, t}=\varepsilon_{z, t}+\varepsilon_{z, t-n}
$$

where $\varepsilon_{z, t}$ is i.i.d. and $z=\{h, c, R, s, p, j, k, m\}$. Thus, at time $t$ agents receive a signal about future macroeconomic conditions at time $t+n$. If the expected movement doesn't occur, then $\varepsilon_{z, t}=-\varepsilon_{z, t-n}$ and $u_{z, t}=0$.

\section{News on Productivity Changes and Boom-Bust Dynamics}

This section reports the dynamics of the model in response to news shocks on future productivity in the consumption and investment sector and assesses their ability to generate boom-bust cycles in the housing market like those seen in the data. We define a boom-bust cycle as a hump-shaped comovement of real house prices, real consumption, real GDP, real business investment, real housing investment, hours in the consumption and in the housing sector, real wages in the consumption and housing sector, nominal interest rate and inflation.

According to Beautry and Portier (2006) business cycle fluctuations in the data are primarily driven by changes in agents' expectations about future technological growth. In fact, they first document that stock prices movements anticipate future growth in total factor productivity and that such dynamics are accompanied by a macroeconomic boom. More recently, Schmitt-Grohe and Uribe (2008) show that innovations in expectations to future neutral productivity shocks, permanent investment-specific shocks, and government spending shocks account for more than two thirds of predicted aggregate fluctuations in postwar United States. ${ }^{9}$ However, as already shown by Beautry and Portier (2004, 2007), a standard one-sector optimal growth model is unable to generate

\footnotetext{
${ }^{8}$ We set the persistence and standard deviation of the shocks as in Iacoviello and Neri (2009).

${ }^{9}$ The empirical literature on news shocks is growing rapidly. Barsky and Sims (2009) show that news shocks on future technology are positively correlated with consumption, stock prices, and consumer confidence innovations
} 
boom-bust cycles in response to news. At the time of the signal consumption increases and hours worked fall thanks to the wealth effect generated by expectations of improved future macroeconomic conditions. Since technology has not improved yet, output decreases. In order for consumption to increase despite the reduction in hours worked, investment has to fall. Thus, good news creates a boom in private consumption and a decline in hours worked, investment and output. A two-sector model with consumption and capital goods is also unable to generate a boom in macroeconomic variables. ${ }^{10}$ When a three-sector model is considered, Beaudry and Portier $(2004,2007)$ show that expectations-driven cycles can arise provided firms exhibit economy of scope or, in other words, internal cost complementarities between the production of different goods.

Jaimovich and Rebelo (2008) introduce three elements in an otherwise standard neoclassical growth model: Variable capital utilization; adjustment costs to investment; and a weak short-run wealth elasticity of labor supply. This latter element is introduced by assuming a generalized version of the preference specification considered by Greenwood, Huffman, Hercowitz (1988). A one-sector model displays co-movement of consumption, output, investment and hours worked in response to news about future total factor productivity or about investment-specific technology. The value of the firm, however, falls unless the production function features decreasing returns to scale as stemming from a factor of production in fixed supply. A two sector model is able to generate co-movement in response to news about future aggregate productivity, productivity in the consumption sector, and productivity in the investment sector only provided the short-run wealth effects on the labor supply are very low, the elasticity of labor supply is high and the elasticity of capacity utilization is low. Jaimovich and Rebelo (2008) also explore a version of their two-sector model with adjustment costs to labor and find they are helpful to generate co-movement in response to news. ${ }^{11}$

and negatively correlated with inflation innovations. Moreover, they explain a large share of variation in aggregate consumption at most horizons but a significant share of stock prices variations only at lower frequencies. Khan and Tsoukalas (2009) suggest that news shocks on productivity are not very important in estimated DSGE models with sticky price and wages. According to Kurmann and Otrok (2010) news shocks about future productivity significantly contribute to explain swings in the slope of the term structure.

${ }^{10}$ News about productivity in the capital sector raises consumption but reduces hours worked. As a result, investment, capital and output fall. An announcement of future higher productivity in the consumption sector generates a boom in all macro variables except consumption for elasticities of intertemporal substitution above one; vice versa, it generates a bust in all macro variables but consumption when the elasticity is below one.

${ }^{11}$ Other papers have focused on different mechanisms. Den Haan and Kaltenbrunner (2006) consider a labor market matching mechanism; Floden (2007) incorporates variable capital utilization and vintage capital; Kobayashi, Nakajima and Inaba (2007) and Walentin (2007) show that expectations-driven cycles can arise in models with credit 
Christiano, Ilut, Motto, and Rostagno (2008) show that a standard one-sector real business cycle model with habit persistence and costs of adjusting the flow of investment generates a boom-bust pattern in output, consumption, investment and hours in response to news on productivity that do not materialize. The price of capital, however, is negatively correlated with all other aggregate variables and therefore it falls and then increases. The introduction of an inflation targeting central bank and sticky nominal wages make the price of capital co-move with the other aggregate variables and boom-bust dynamics emerge. When news spreads about a future increase in productivity, aggregate variables increase including hours worked. The increase in hours is possible because the real wage falls, hence producers are willing to raise labor demand. Since nominal wages are sticky, a decrease in real wages occurs because prices increase faster than wages.

We show that also in a model of the housing market that features collateralized household debt and standard preferences and production functions, empirically plausible boom-bust cycles emerge if nominal rigidities, both in prices and wages, are assumed. However, contrary to Christiano et al. (2008), we obtain boom-bust dynamics in all aggregate variables and real wages. This outcome arises independently of whether wages are stickier than prices or vice versa. Intuitively, the increase in housing demand and therefore housing prices in response to news allows for an increase in both real wages and hours in the housing sector that spills over the consumption sector. In the following section we document that during periods of boom-bust cycles in the housing market, on average, real wages co-move with other aggregate variables.

In Christiano et al. (2008) real wages fall and remain below trend for most of the boom phase and then increase shortly before the period when the shock is going to be realized (or not). The empirical evidence in Figure 3 seems to suggest that real wages are not below trend before a peak in house prices and that they increase throughout the boom phase. Notice also that the asset-price peak in the third quarter of the year 2000 to which Christiano et al. (2008) refer to was preceded by rapid growth of real wages both in the consumption-good and in the housing sector - see Figure 1 - and real wages were also above trend.

\subsection{Productivity in the Consumption-Good Sector of Production}

Figure 8 reports the effect of anticipated future productivity gains, namely a shock to $A_{c}$ (starred line). It also illustrates the case in which the expected increase in productivity turns out to be wrong and at time $t=4$ there is no change in productivity (solid line). The dashed line displays

constraints on firms; Nutahara (2009) prove that in contrast to external habits, internal habits can help to generate co-movement in response to news on future productivity. 
the effects of a current unanticipated productivity shock.

Expectations of future productivity gains generate boom-bust dynamics in GDP, consumption, hours, investment and house prices. The intuition is as follows. Expectations of higher productivity in the future lead households to increase their current consumption expenditure. Due to demand pressures, inflation increases. At the same time, the anticipation of higher productivity in the future generates expectations of higher future housing prices. The decline in the current real rate coupled with higher expected housing prices lead to an increase in Borrowers' housing expenditure and indebtedness. Due to limits to credit, impatient households increase their labor supply in order to raise internal funds for housing investment.

Given the adjustment costs of capital, firms in the consumption sector start adjusting the stock of capital already at the time in which news about a future increase in productivity spreads. This way, when the increase in productivity occurs, capital is already in place. For the increase in business investment to be coupled with an increase in total hours worked, wages must rise. GDP increases already at the time of the signal.

The model presented above features several real and nominal rigidities. In order to disentangle the contribution of the different modeling choices, we introduce the frictions one at the time. Figure 9 displays the boom-bust response to news on productivity in the flexible-price version of the model. In the absence of adjustment costs of capital and when impatient households cannot borrow (dashed line), i.e. when $m=0$, the wealth effect dominates and agents increase both consumption and leisure. To increase consumption households reduce their investment expenditures (in all sectors). When it is costly to adjust the stock of capital, the reduction in business investment and thus the increase in consumption is less pronounced (starred line). Allowing for borrowing against the value of the collateral leads to a more pronounced increase in Borrower's housing demand (solid line). In this last case, Borrower's consumption increases by more in the boom phase and the decline in Borrower's hours (not shown in the graph) is more sizable. Saver's demand for housing declines. Since Savers account for about eighty percent of labor income, aggregate housing production declines and housing prices fall. To sum up, adjustment costs and the collateral effect are not enough to generate boom-bust dynamics in the absence of nominal rigidities.

Figures 10 shows the response of the economy with nominal rigidity in the price of the consumption good but no wage rigidities (dashed line). Expectations of higher future productivity lead to a decrease in expected inflation, which in turn reduces the expected real interest rate. The decline in the current real interest rate coupled with a higher expected real rate lead to an increase in current debt and thus Borrowers' consumption, Borrowers' housing demand and Savers' 
consumption. On the contrary, Savers reduce their housing demand and increase their supply of labor. For a contemporaneous increase in business investment and hours, the rise in wages in the consumption sector needs to be significant. Aggregate housing investment first declines and then slowly increases; housing prices increase as well as current inflation. However, compared to the case with flexible prices, inflation rises by less, thereby allowing for a more pronounced increase in consumption.

In the additional presence of wage stickiness in the consumption sector, the wage in the consumption sector increases by less (starred line), which raises the demand for labor and therefore hours in the consumption sector. Moreover, since the sectorial wage differential is more pronounced, Savers increase their labor supply in the housing sector as well. Thus, the model displays co-movement of GDP, consumption, business investment and housing prices over the boom-bust cycle. Housing investment and hours in the housing sector, however, fall because wages in the housing sector increase substantially, thereby reducing labor demand in the sector. To obtain a boom in investment and hours in the housing sector it is necessary to introduce wage stickiness in the housing sector.

Finally, we add wage stickiness in both sectors of production (solid line). Since wage stickiness is more sizable in the housing sector, the increase in wage in that sector is less pronounced. Due to a further reduction in the current income effect, agents increase their labor supply by more. Aggregate housing investment increases more so that housing prices rise less. Household debt increases less but aggregate consumption is barely affected relative to the case of no wage stickiness in the housing sector. Thus, in the presence of nominal price and wage rigidities, expectations of future productivity gains generate empirically plausible boom-bust cycle dynamics. This result is robust to different parametrization of the labor share income of credit-constrained agents, $\alpha$, the loan-to-value ratio, $m$, the capacity utilization rate, $z_{c, t}$, and the labor mobility across sectors, $\xi$ and $\xi^{\prime}$. See Appendix C.

\subsection{Investment-specific Shock}

Figure 11 shows the effects of expectations of a future increase in the cost of transforming output into capital, $A_{k}$. Agents are willing to increase their labor supply in order to reduce the future negative effect of the shock. Consumption and housing expenditures increase. The increase in aggregate housing demand makes housing prices rise as well. Housing investment increases. Thus, the stock of capital used as input of production increases in both the consumption- and housinggood sector and total business investment goes up. As a result of the increase in the production of consumption goods, housing investment and business investment, GDP rises. 
A four-period anticipated increase in the capital production cost generates a boom in housing prices, housing investment, consumption, GDP, hours and indebtedness. The peak response of all aggregate variables corresponds to the time in which expectations realize. After that all variables slowly return to their initial values. In contrast, if expectations do not realize there is a dramatic drop in both quantities and prices (solid line).

\section{Expectations on future Macroeconomic Developments and Boom-Bust Dynamics}

The existing literature on boom-bust cycles focuses mainly on expectations of future macroeconomic developments related to productivity and investment-specific shocks. A novel element in this paper is the introduction of changes in expectations on several other shocks that originate in the housing market, the credit market and the conduct of monetary policy. In the following we show that changes in expectations about future housing supply, inflation, the policy rate and the central bank's target can also generate housing-market boom-bust cycles characterized by co-movement in GDP, consumption, investment, hours and real wages.

\subsection{Productivity and Demand in the Housing Market}

Iacoviello and Neri (2009) document that housing demand and supply shocks explain each onequarter of fluctuations in housing prices and housing investment. We show that only expectations of a future reduction in the supply of houses generate boom-bust cycles in all aggregate quantities such as output, consumption, hours and investment. In contrast, expectations of a future increase in housing demand reduce business investment and therefore fail to generate co-movement in aggregate variables.

Figure 12 shows that expectations of a future decline in productivity in the housing sector, a fall in $A_{h}$, make agents increase their labor supply in order to reduce the future negative effect of the shock. Moreover, news of negative housing supply shocks generates expectations of a future increase in house prices. To take advantage of lower current prices, Borrowers increase their current housing demand. Thus, both indebtedness and consumption expenditure increase. Due to adjustment costs in capital, firms start adjusting the stock of capital already at the time of news. ${ }^{12}$ As a result, business investment slightly decreases on impact. Despite this, GDP rises due to the increase in housing investment and consumption. A four-period anticipated decline in productivity

\footnotetext{
${ }^{12}$ The stock of capital (not shown in the graph) used as input of production in the consumption sector increases while it decreases in the housing sector.
} 
(starred line) generates a boom in housing prices, housing investment, consumption, GDP, hours and indebtedness. Still, current business investment slightly falls. This is consistent with business investment being slightly below trend at the beginning of a boom-bust episode. See Figure 3 .

Figure 13 shows the response of the model economy to expectations of a future increase in housing demand due to a housing preference shock, an increase in $j$. Anticipating a future increase in housing prices, Borrowers raise their current demand for houses and thus indebtedness and consumption. Firms in the housing sector start adjusting their capital holding at the time of the signal and housing investment increases. Due to an expected shift in preference for housing relative to consumption, firms in the consumption sector reduce their stock of capital. As a result, business investment falls. Despite the decline in business investment, GDP rises. Because of the reduction in business investment during the boom phase, news about a future increase in housing demand fails to generate boom-bust dynamics consistent with the empirical pattern. In the data business investment starts increasing already six periods before the peak in housing prices; in the model however it declines throughout the boom phase. Figure 14 considers the effect of an anticipated increase in housing demand at different time horizons: $n=\{4,6,8\}$. Expectations of a change in housing demand further in the future only postpone the occurrence of the peak. The behavior of business investment is independent of the time horizon of the expected increase in housing demand. The decline in business investment is also robust to different parametrization of other key model parameters. See Appendix C.

\subsection{Monetary Policy and Inflation}

In the following we study the role of expectations of future monetary policy developments in driving business cycle fluctuations in the housing market. We document that expectations of a reduction of the policy rate or of an increase in the central bank's inflation target generate macroeconomic booms that turn into busts if agents' expectations are not realized ex-post. We also consider expected future downward pressures in inflation, which also generate boom-bust dynamics.

A current unexpected decline in the interest rate - i.e. a negative realization of $\epsilon_{R, t}$ - induces agents to increase their current expenditures. See the dashed line in Figure 15. Aggregate demand rises. Borrowers significantly increase their level of indebtedness and housing investment. Housing prices rise and the subsequent collateral effect induces a sizable increase in Borrowers' consumption. 
Even though aggregate variables increase, they do not display hump-shaped dynamics.

Expectations of a future decrease in the policy rate (news of a future negative shock to $u_{R}$ ) that do not realize can generate macroeconomic boom-bust dynamics. See the starred line in Figure 15 for the response to an expected one-period reduction in the policy rate of 0.1 percentage points. The intuition is as follows. Signals of lower policy rates generate expectations of a decline in the future real interest rate. Borrowers anticipate this effect and increase their current consumption as servicing loans will be less expensive. Demand pressure rises current inflation. The current ex-post real rate declines reducing the debt service. The anticipation of expansionary monetary policy also creates expectations of higher future housing prices that further induce Borrowers to increase their current demand for housing and thus indebtedness. Due to limits to credit, impatient households increase their labor supply in order to raise internal funds for housing investments. Savers face a reduction in their current and expected interest income. Thus, for this group of agents consumption increases by less, current housing investment declines and their labor supply increases significantly.

Due to capital adjustment costs, firms already begin adjusting the stock of capital when news about a future reduction in the policy rate spreads. For the increase in investment to be coupled with an increase in hours, wages rise in both sectors. The increase in business and housing investment makes GDP increase already at the time of the signal. ${ }^{13}$

In the case of an anticipated shock that realizes (starred line), aggregate variables boom and then slowly decline. The peak response in output corresponds to the time in which expectations realize. In contrast, if expectations do not realize there is a dramatic drop in both quantities and prices (solid line). Aggregate variables fall below their initial level. It takes about ten quarters for GDP to go back to the initial level. Thus, expectations of looser monetary policy that do not realize generate a macroeconomic boom-bust cycle followed by a recession.

We also consider the case where agents expect a persistent reduction in the policy rate. For this experiment we set the persistence of the shock $u_{R, t}$ equal to 0.65 in order to capture the situation where agents expect the policy rate to remain low for several periods. The impulse responses are shown in Figure 16. In this case, the effect on housing prices and on all other aggregate variables is stronger and the initial boom and the subsequent recession are more pronounced relative to the

\footnotetext{
${ }^{13}$ As a consequence of the current increase in inflation and GDP, the policy rate (not shown in the graph) increases at the time of the signal, to decline only at the time of occurrence of the shock.
} 
case where agents expect only a one-period reduction in the policy rate.

Figure 17 documents the effect of expectations of a temporary but persistent upward deviation in the central bank's inflation target, a negative realization of $u_{s}$. The anticipation of a higher target for inflation means higher long-run expected inflation. Firms that can change prices adjust them upwards already in the current period. Thus, expectations of higher future inflation increase inflation already in the current period. Expectations of a future reduction of the ex-post real interest rate coupled with a current reduction in the nominal interest rate induce an increase in household indebtedness, higher consumption and higher housing spending. Housing prices and housing investment increase. Due to adjustment costs to capital, firms start adjusting the stock of capital already at the time of the signal. Real wages and hours worked rise. The economy experiences a macroeconomic boom. After the shock is realized all variables slowly return to their initial levels. Figure 17 also displays the behavior of the model economy when news on future central bank's target does not realize, i.e. the target does not increase in period $t=4$. As expected, at time $t=5$ quantities and prices drop. Housing prices, investment and GDP do not display an humpshaped pattern. Compared to the case of expectations of future expansionary monetary policy, expectations of a temporary upward shift in the inflation target generate a less sizable boom but a more pronounced bust.

Figure 18 documents how expected future downward pressure on inflation, namely a future negative shock to $u_{p}$, affects the dynamics of the model. Because of price stickiness, some firms already adjust their prices downwards when news spreads. Thus, expectations of lower inflation in the future reduce inflation instantaneously. Current consumption expenditure increases, as well as investment. Expectations of higher future housing prices induce Borrowers to increase their current demand for housing and therefore indebtedness. On the other hand, a reduction in inflation raises the rate of return on nominal assets and makes them more attractive. As a result, Savers increase the supply of loans and persistently decrease their demand for housing. Compared to the previous cases, expectations of a future reduction in inflation lead to a more sizable boom but a milder bust. 


\subsection{Credit Shocks and Boom-Bust Cycles}

The results presented above show that the increase in housing prices generated by changes in households' expectations is coupled with an endogenous increase in household indebtedness. An often-heard explanation for the last housing boom is an easing of credit conditions. In the following we analyze the effects of an exogenous change in the access to credit as proxied by shocks to the established loan-to-value ratio - in terms of our model, $m$.

We first document the effects of a current unexpected increase in the loan-to-value ratio. To illustrate the effect of changes in the access to credit, we assume that $m$ follows an $\operatorname{AR}(1)$ process with persistence equal to 0.994 , as estimated by Iacoviello and Neri (2009). ${ }^{14}$ The dotted line in Figure 19 shows the effect of a one percentage point temporary increase in the access to credit, namely a current increase in $m$. Borrower's debt and therefore consumption and housing demand increase, which leads to a rise in aggregate consumption, investment and GDP. Demand pressures make housing prices rise; inflation barely rises. However, the model's responses do not display the hump-shaped dynamics that typically emerge in boom-bust cycles. The shock leads to an initial increase in house prices, investment, consumption and GDP and a subsequent, slow monotone decline toward the initial level.

The starred line in Figure 19 shows the dynamics when agents expect a future increase in credit market access, i.e. a future increase in $m$. The solid line corresponds to the case where expectations do not materialize. When Borrowers forecast an increase in the access to credit, they postpone housing investment but already increase their consumption. On the other hand, Savers forecast future higher real interest rates and respond by reducing consumption. Because a future increase in $m$ will generate an increase in housing demand at the expenses of consumption demand, firms in the consumption sector reduce their capital. As a result, business investment falls. Hence, news about a future increase in the access to credit generate opposite movements in business investment and consumption, unlike what happens during a housing peak.

Finally we consider the case in which agents expect the current favorable credit conditions to be reversed in the near future. Figure 20 shows the effects of a one-percent current increase in $m$ coupled with expectations of future restrictions in the access to credit, namely with expectations

\footnotetext{
${ }^{14}$ See Iacoviello and Neri (2009), Appendix D.
} 
that $m$ will return to its original value after four periods (starred line). For simplicity we analyze only the case in which news materialize. This is compared to a current unanticipated increase in $m$ (dotted line). Relative to the previous case, the impact on most variables is more sizable. Lower expected access to credit in the future induces Borrowers to increase their current demand for loans and housing more relative to the cases analyzed above. As a result, the increase in housing prices and housing investment is more pronounced. Borrowers substitute consumption for housing and supply more labor in order to raise internal funds and take advantage of temporarily better access to credit. In contrast, Savers' consumption increases due to future lower real interest rates and habit persistence in consumption. Aggregate consumption increases as well as GDP. Hours worked increase substantially in both sectors. As a result, inflation and real wages fall slightly. Interestingly, the dynamics of real wages is consistent with the empirical evidence on the housing peak of 2006:2. The dynamics of inflation, however, is not consistent with such evidence. ${ }^{15}$ To sum up, a current increase in the access to credit that is expected to be reversed in the future generates boom-bust dynamics in most aggregate variables, with the exception of real wages and inflation.

\section{Conclusions}

We study the role of expectations-driven fluctuations in generating boom-bust cycle dynamics in the housing market. First, we document that the cyclical behavior of housing prices and housing investment is coupled with a similar pattern in GDP, business investment, consumption, hours worked and real wages. Then we show that changes in expectations about the future state of productivity, investment cost, housing supply, inflation, the policy rate and the central bank's target can generate housing-market boom-bust cycles in accordance with the empirical findings. In contrast, expectations on future housing demand does not generate co-movement between business investment and all other aggregate variables.

Anticipated as well as unanticipated increases in the access to credit fail to generate comovement between aggregate variables and business investment. On the other hand, a current easing of credit conditions that is expected to be reversed in the near future delivers boom-bust dynamics housing prices, housing and business investment, GDP, consumption and hours but not

\footnotetext{
${ }^{15}$ See Appendix B.
} 
in real wages and inflation.

In the presence of nominal rigidities, expectations on the conduct of monetary policy and future productivity can be a source of fluctuations in the housing market. However, only expectations of either a future reduction in the policy rate or a temporary increase in the central bank's inflation target that are not fulfilled can generate macroeconomic recessions. Our results imply that good communication on monetary policy is essential for reducing the occurrence of expectations-driven cycles.

A quantitative assessment of the relative importance of each shock in generating boom-bust cycles through estimation requires separate consideration. The role of monetary policy, as well as the analysis of the optimal conduct of monetary policy, is also left to future research. 


\section{References}

[1] Ahearne, A.G., J. Ammer, B.M. Doyle, L.S. Kole and R.F. Martin. 2005. "House Prices and Monetary Policy: A Cross-Country Study." Board of Governors of the Federal Reserve System International Finance Discussion Papers 841.

[2] Barsky, R. B. and E. R. Sims (2009). "News Shocks, "mimeo.

[3] Basant Roi, M. and R. Mendes, 2007. "Should Central Banks Adjust Their Target Horizons in Response to House-Price Bubbles?" Bank of Canada Discussion Papers 07-4.

[4] Beaudry, P. and F. Portier, 2004. "An Exploration into Pigou's Theory of Cycles," Journal of Monetary Economics, 51: 1183-1216.

[5] Beaudry, P. and F. Portier, 2006. "Stock Prices, News, and Economic Fluctuations," American Economic Review, 96(4): 1293-1307.

[6] Beaudry, P. and F. Portier, 2007. "When can Changes in Expectations Cause Business Cycle Fluctuations in Neo-classical Settings?." Journal of Economic Theory, 135(1): 458-477.

[7] Bernanke B. and M.Gertler. 1999. "Monetary Policy and Asset Price Volatility". In New Challenges for Monetary Policy, 77-128, Federal Reserve Bank of Kansas City.

[8] Campbell, J. 1994. "Inspecting the Mechanism: an Analytical Approach to the Stochastic Growth Model". Journal of Monetary Economics, 33(3): 463-506.

[9] Cecchetti, S., H. Genberg and S. Wadhwani. 2003. "Asset Prices in a Flexible Inflation Targeting Framework." In Asset Price Bubbles: The Implications for Monetary, Regulatory and International Policies, 427-44. Cambridge, MA: MIT Press.

[10] Christiano, L., C. Ilut, R. Motto, and M. Rostagno. 2008. "Monetary Policy and Stock Market Boom-Bust Cycles.” ECB Working Paper Series 955.

[11] Den Haan, W.J., and G. Kaltenbrunner, 2007. "Anticipated Growth and Business Cycles in Matching models." CEPR Discussion Paper 6063. 
[12] Floden, M., 2007. "Vintage Capital and Expectations Driven Business Cycles." CEPR Discussion Paper 6113.

[13] Greenwood, J., G. W. Huffman, and Z. Hercowitz, (1988), Investment, Capacity Utilization, and the Real Business Cycle, American Economic Review, vol. 78.

[14] Horvath, M., 2000. "Sectoral Shocks and Aggregate Fluctuations." Journal of Monetary Economics, 45(1):69-106.

[15] Iacoviello, M., 2005. "House Prices, Borrowing Constraints, and Monetary Policy in the Business Cycle." American Economic Review, 95(3): 739-64.

[16] Iacoviello, M. and S. Neri, 2009. "Housing Market Spillovers: Evidence from an Estimated DSGE Model." AEJ Macro, forthcoming.

[17] Jaimovich, N. and S. Rebelo, 2009. "Can News about the Future Drive the Business Cycle?", American Economic Review, forthcoming.

[18] Kannan, P., Rabanal, P. and A. Scott, 2009. "Macroeconomic Patterns and Monetary Policy in the Run-Up to Asset Price Busts", IMF Working Paper 09/252.

[19] Kengo, N, 2009. "Internal and External Habits and News-driven Business Cycles", MPRA.

[20] Khan, H. and J. Tsoukalas, 2009. " The Quantitative Importance of News Shocks in Estimated DSGE Models" mimeo.

[21] Kiyotaki, N. and J. Moore, 1997. "Credit Cycles," Journal of Political Economy, 105, April 211-48.

[22] Kobayashi, K., T. Nakajima and M. Inaba, 2007. "Collateral Constraint and News-driven Cycles." Discussion paper 07013, Research Institute of Economy, Trade and Industry (RIETI).

[23] Kurmann, A. and C. Otrok, 2010. "News Shocks and the Slope of the Terms Strucure of Interest Rates" mimeo.

[24] Schmitt-Grohe s. and M. Uribe. 2008. "What's News in Business Cycles". NBER Working Paper No. 14215 
[25] Walentin, K., 2009. "Expectation Driven Business Cycles with Limited Enforcement," Working Paper Series 229, Sveriges Riksbank.

[26] Wouters R., and F. Smets, 2003. "Output Gaps: Theory versus Practice," Computing in Economics and Finance, 2003256. 


\section{Appendix}

\section{A Data}

CC : Aggregate Consumption. Real Personal Consumption Expenditure (seasonally adjusted, billions of chained 2005 dollars, Table 1.1.6), divided by the Civilian Noninstitutional Population (CNP16OV, source: Bureau of Labor Statistics). Source: Bureau of Economic Analysis (BEA).

GDP : Gross Domestic Product. Real Gross Domestic Product (seasonally adjusted, billions of chained 2005 dollars, Table 1.1.6), divided by CNP16OV. Source: BEA.

IK : Business Fixed Investment. Real Private Nonresidential Fixed Investment (seasonally adjusted, billions of chained 2005 dollars, Table 1.1.6), divided by CNP16OV. Source: BEA.

IH : Residential Investment. Real Private Residential Fixed Investment (seasonally adjusted, billions of chained 2005 dollars, Table 1.1.6.), divided by CNP16OV. Source: BEA.

INFLQ : Inflation. Quarter on quarter log differences in the implicit price deflator for the nonfarm business sector, demeaned. Source: Bureau of Labor Statistics (BLS).

RRQ : Nominal Short-term Interest Rate. 3-month Treasury Bill Rate (Secondary Market Rate), expressed in quarterly units. (Series ID: H15/RIFSGFSM03_NM). Source: Board of Governors of the Federal Reserve System.

QQ : Real House Prices. Census Bureau House Price Index (new one-family houses sold including value of lot) deflated with the implicit price deflator for the nonfarm business sector. Source: Census Bureau, http://www.census.gov/const/price_sold_cust.xls.

NC : Hours in Consumption Sector. Total Nonfarm Payrolls (Series ID: PAYEMS in Saint Louis Fed Fred2) less all employees in the construction sector (Series ID: USCONS), times Average Weekly Hours of Production Workers (series ID: CES0500000007), divided by CNP160V. Source: BLS. 
NH : Hours in Housing Sector. All Employees in the Construction Sector (Series ID: USCONS in Saint Louis Fed Fred2), times Average Weekly Hours of Construction Workers (series ID: CES2000000007), divided by CNP16OV. Source: BLS

RWCPC : Real Wage in Consumption-good Sector. Average Hourly Earnings of Production/ Nonsupervisory Workers on Private Nonfarm Payrolls, Total Private (Series ID: CES0500000008), divided by the price index for Personal Consumption Expenditure (Table 2.3.4, source: BEA). Source: BLS.

RWHPC : Real Wage in Housing Sector. Average Hourly Earnings of Production/Nonsupervisory Workers in the Construction Industry (Series ID: CES2000000008), divided by the price index for Personal Consumption Expenditure (Table 2.3.4, source: BEA). Source: BLS.

RLOANS : Households and nonprofit organizations home mortgages liability (seasonally adjusted, millions of current dollars), divided by the implicit price deflator and divided by the Civilian Noninstitutional Population. Source: The Federal Reserve Board (Series ID: Z1/Z1/LA153165105.Q).

Note: In the figures and tables GDP, Consumption, Business Investment, Residential Investment, Real Loans, Hours in the Consumption Sector, Hours in the Housing Sector, House Prices, Real Wage in the Consumption Sector and Real Wage in the Housing Sector are log-transformed and normalized to zero in 1965:1. 


\section{B Housing Prices Peaks: 1965:1-2009:2}

Figures 4 to 7 illustrate the behavior of our macroeconomic variables (not Hodrick-Prescott filtered) during the four housing peak episodes. These graphs show that the behavior of our "average" series represents well the four episodes. In all cases, real GDP, private consumption, real private residential and nonresidential fixed investment co-move with real house prices in a bell-shaped dynamics. Real loans display hump-shaped dynamics after H-P filtering; without filtering, real loans grow during the boom phase and stabilize during the bust phase.

The specific episodes illustrated in Figures 4 to 7 reveal that, with the exception of the 1989:2 episode, real loans peak at the beginning of the recession that follows the bust in housing prices. In the housing peaks of 1973:3 and 1979:4 the recession and the peak in real loans come right after the peak in housing prices; on the other hand, in the last housing boom-bust episode the recession started in 2007:4, six quarters after the peak in housing prices. The housing price peak of 1989:2 is an exception because it was not characterized by a fall in real loans. Notice however that the housing peak of 1989:2 is the mildest in our sample and the economic recession of 1990:3 to 1991:1 that followed the peak is the shortest and mildest in our sample as well.

Even thought the average over all peaks captures well all single episodes, there are some small differences that are worth commenting on. Inflation behaves differently in the 1973:3 boom-bust episode. Inflation decreases slightly in the ten quarters preceding the peak in real house prices and then increases from four to sixteen percentage points in the next six quarters, from 1973:3 to 1975:1. Notice, however, that inflation is already high at the beginning of the boom-bust episode as a consequence of the Vietnam War. Moreover, the first oil shock contributes to the sharp rise in inflation of 1975:1, the highest level since World War I.

Real wages behave differently in the housing peak of 2006:2 relative to the previous ones. In fact, the peak in real house prices occurs roughly at the trough of real wages in both sectors. In particular, it appears that nominal wages (not shown) did not fall at all in the construction sector and fell very little in the consumption-good sector since the beginning of the recession. We speculate that the real wage dynamics in the last boom-bust episode are driven by the combination of rapidly falling prices and sticky nominal wages that have not been adjusted yet.

At last, it is worth noticing that all four peak episodes have occurred in the context of raising 
oil prices, which is likely to have contributed to the recessions that followed the housing busts.

Our housing peaks are robust to using the OFHEO index. Our peaks are very close to those found by Ahearne et al. (2005), who use the single-family house price index from OFHEO for the United States. Ahearne et al. (2005) identify the following peaks in the U.S. housing market: 1973:4 (we find 1973:3), 1979:2 (we find 1979:4), 1989:4 (we find 1989:2). They do not find the last housing peak because their sample ends in 2004:4.

\section{Sensitivity Analysis}

The results presented in Sections 4 and 5 are robust to different parametrization of the labor share income of credit-constrained agents, $\alpha$, the loan-to-value ratio, $m$, the capacity utilization rate, $z_{c, t}$, and the labor mobility across sectors, $\xi$ and $\xi^{\prime}$. We consider the parameter values at the mean (benchmark case), at the 2.5 and the 97.5 percent probability interval of the posterior distribution as estimated by Iacoviello and Neri (2009). Figures 21 to 24 illustrate the implications of different parameter values. All figures show very little sensitivity in the response of the aggregate variables to these parameters. 


\begin{tabular}{|c|c|c|}
\hline \multicolumn{3}{|c|}{ Correlation with QQHP } \\
\hline & $1965: 1$ to $2009: 2$ & Boom-Bust Episodes \\
\hline GDPHP & 0.60 & 0.64 \\
\hline CCHP & 0.54 & 0.60 \\
\hline IKHP & 0.55 & 0.58 \\
\hline IHHP & 0.49 & 0.53 \\
\hline RLOANSHP & 0.76 & 0.84 \\
\hline NCHP & 0.62 & 0.62 \\
\hline NHHP & 0.71 & 0.71 \\
\hline RRQHP & 0.50 & 0.44 \\
\hline INFLQHP & 0.29 & 0.23 \\
\hline RWCPCHP & 0.20 & 0.31 \\
\hline RWHPCHP & -0.10 & 0 \\
\hline \multicolumn{3}{|c|}{ Standard Deviation } \\
\hline GDPHP & 1.56 & 1.65 \\
\hline $\mathrm{CCHP}$ & 1.85 & 2.13 \\
\hline IKHP & 5.08 & 4.83 \\
\hline IHHP & 10.23 & 12.41 \\
\hline RLOANSHP & 2.46 & 2.47 \\
\hline NCHP & 1.69 & 1.76 \\
\hline NHHP & 4.38 & 4.60 \\
\hline RRQHP & 0.31 & 0.37 \\
\hline INFLQHP & 0.40 & 0.51 \\
\hline RWCPCHP & 0.99 & 1.32 \\
\hline RWHPCHP & 1.15 & 1.42 \\
\hline QQHP & 2.23 & 2.31 \\
\hline
\end{tabular}

Table 1: Descriptive Statistics for H-P filtered data: Full Sample and Boom-Bust Episodes. All series are de-trended using the H-P filter. Standard deviation in percentage points. 

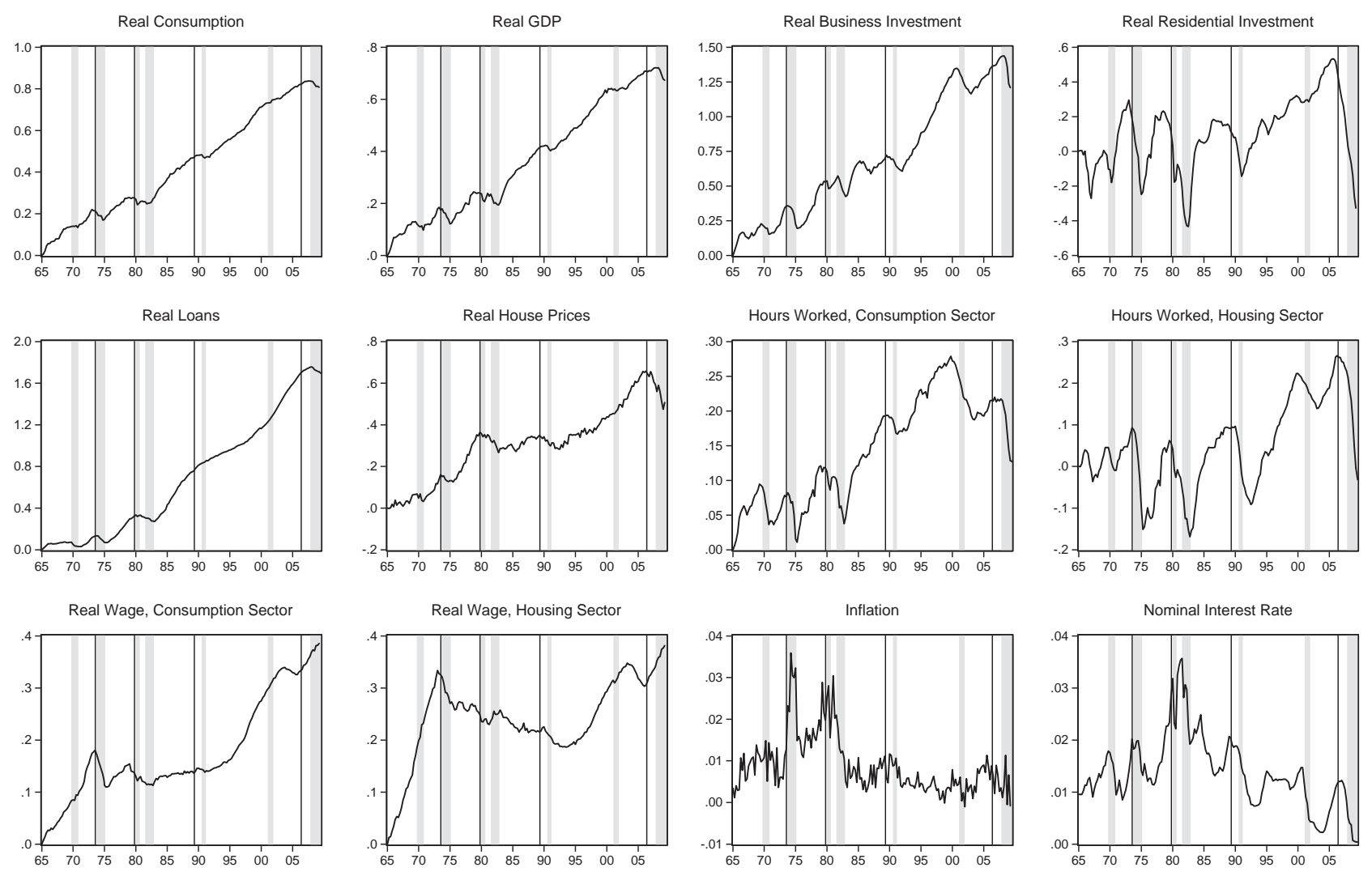

Figure 1: Macroeconomic Variables in the United States, 1965:1 to 2009:2

Note: Vertical lines indicate peaks in real house prices. Shaded areas indicate recessions according to the NBER. 

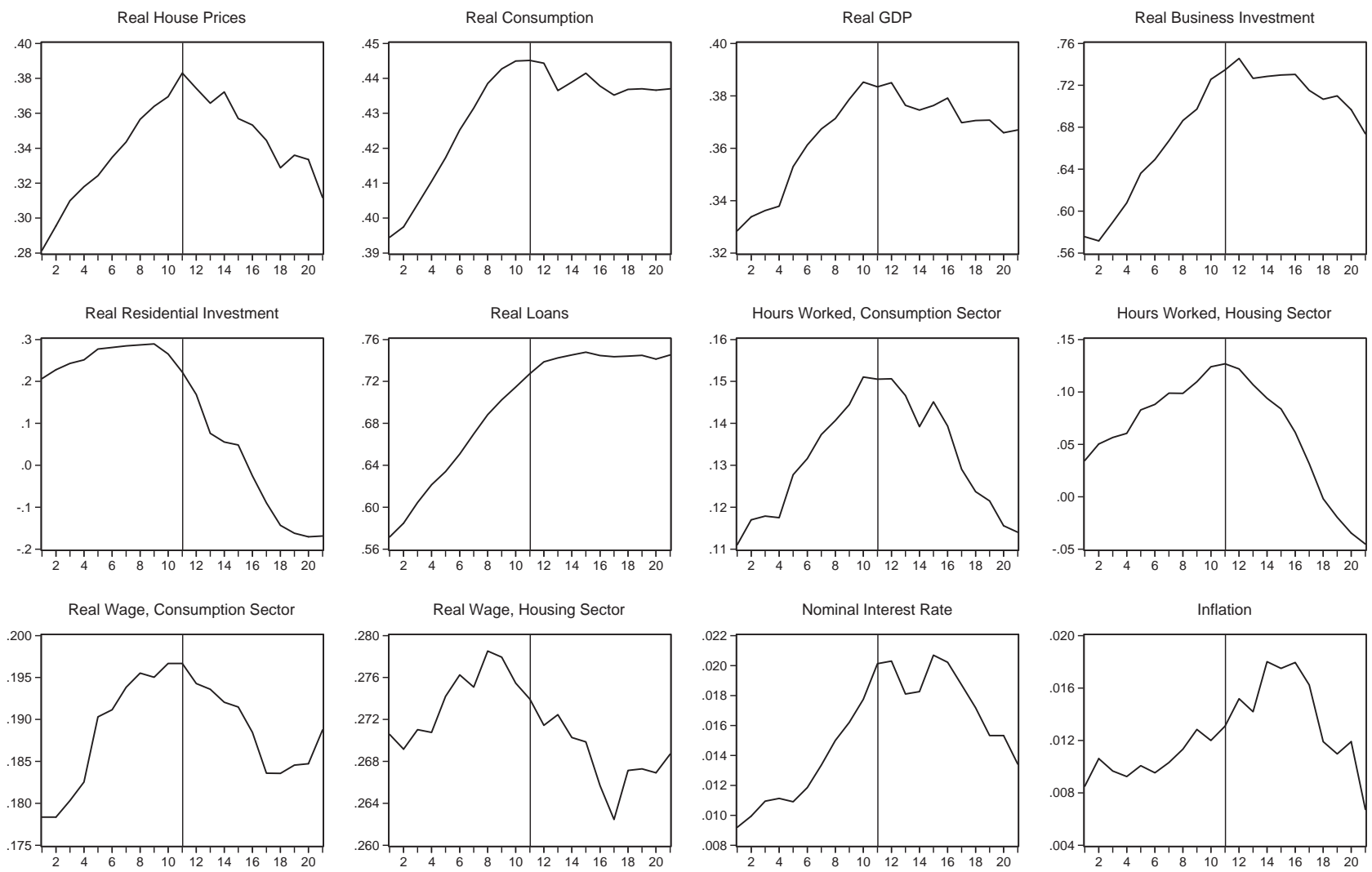

Figure 2: Macroeconomic Variables during Peaks: Average over all Peaks
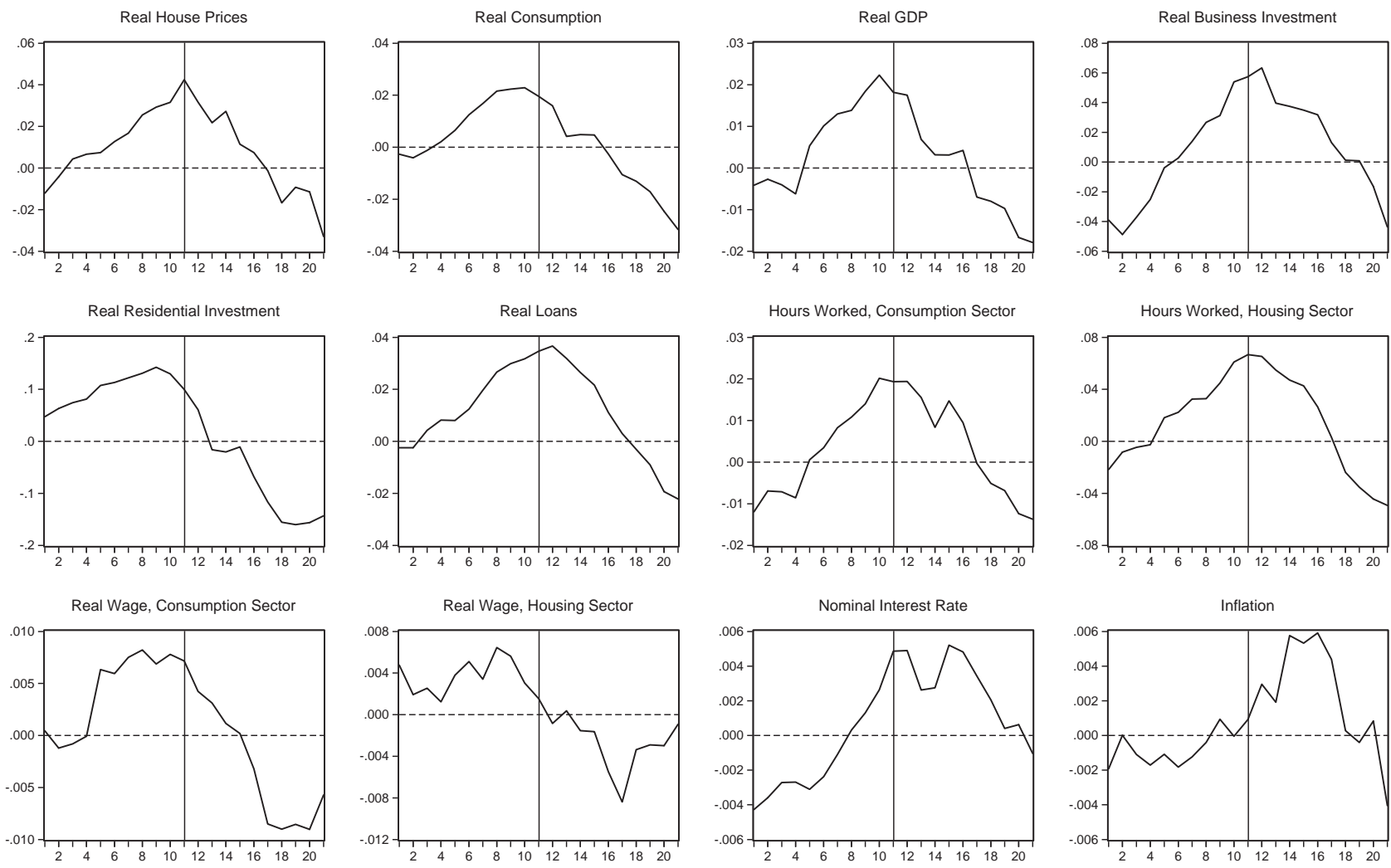

Figure 3: H-P-filtered Macroeconomic Variables during Peaks: Average over all Peaks 

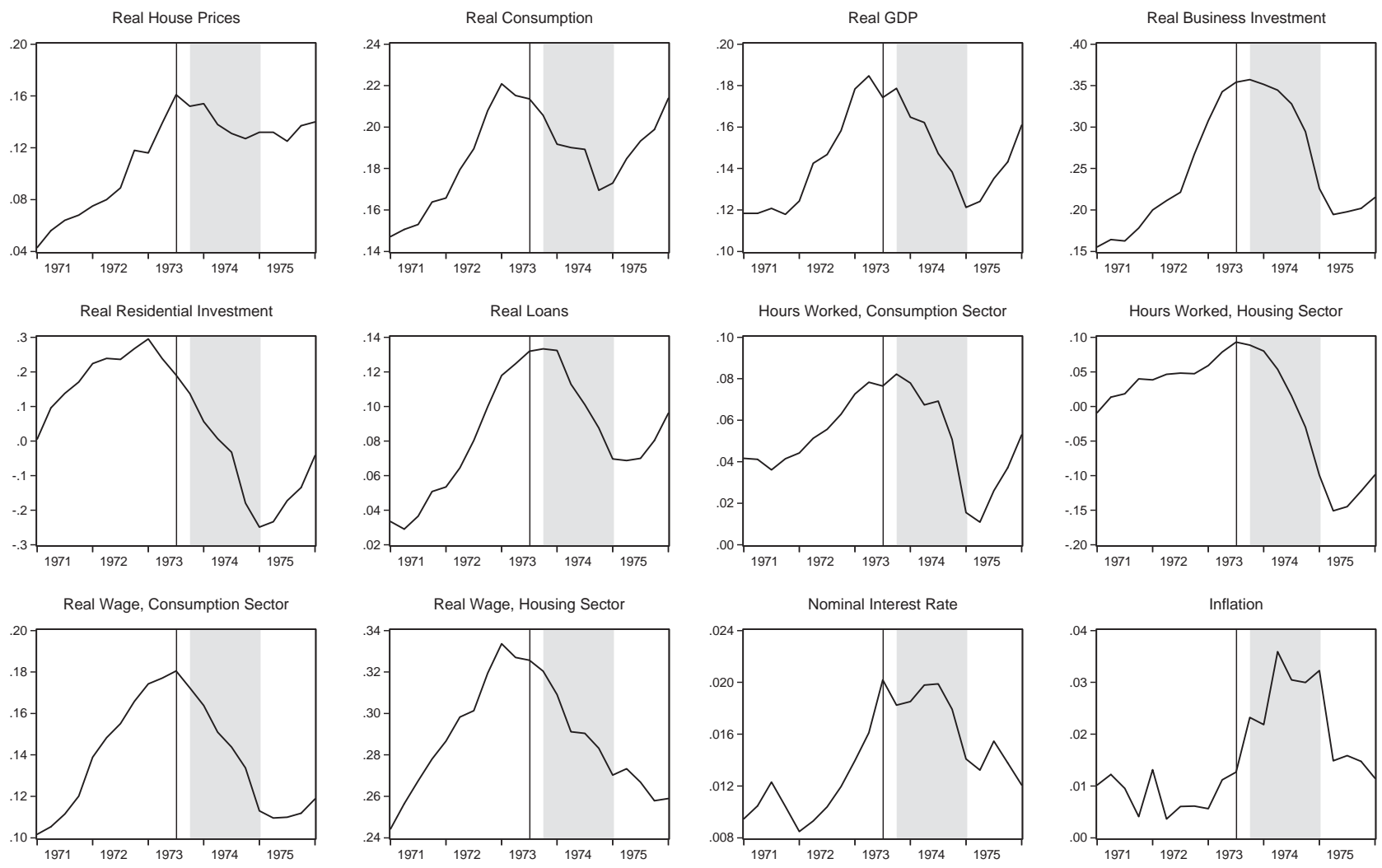

Figure 4: 1973:3 Peak
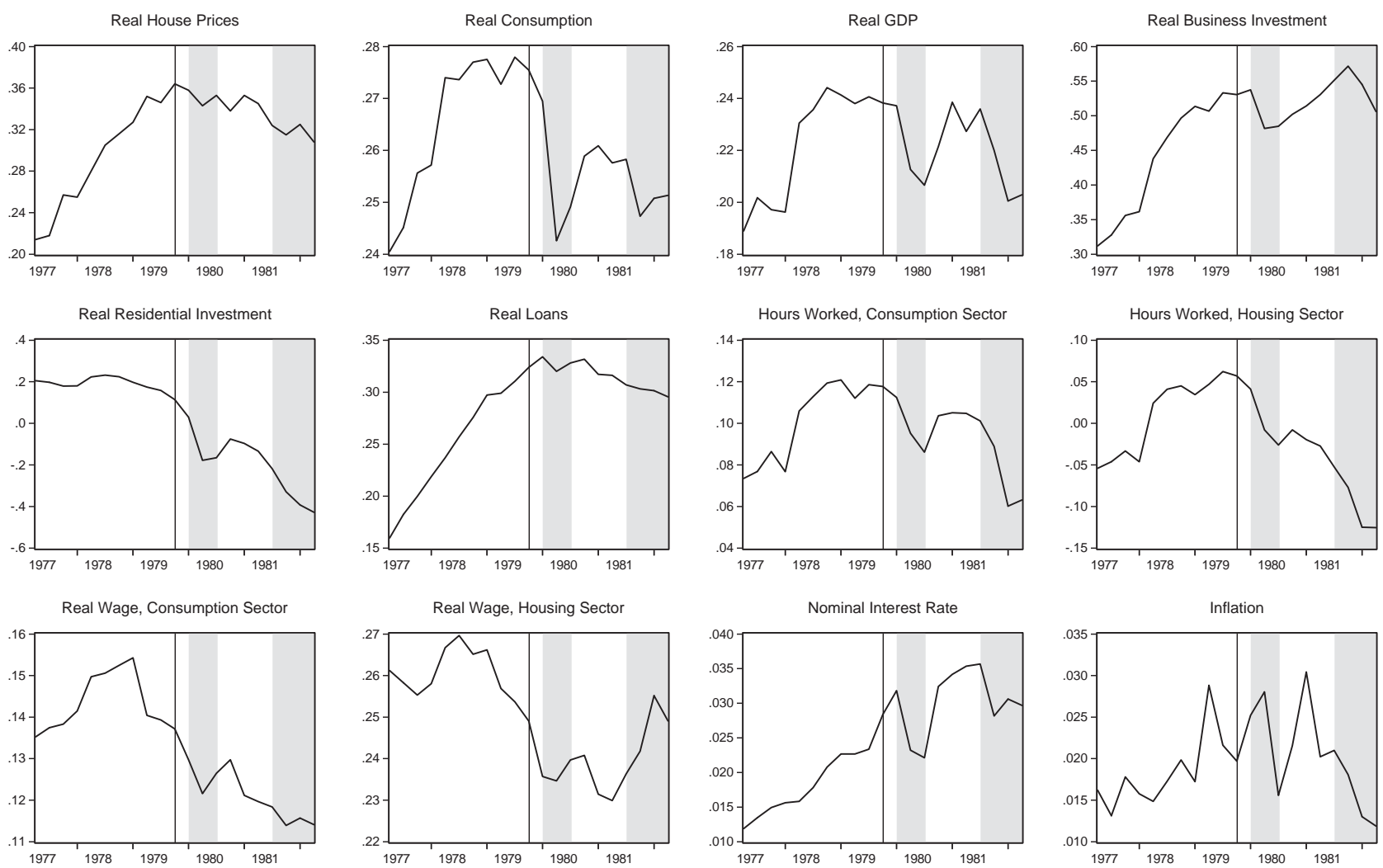

Figure 5: 1979:4 Peak 

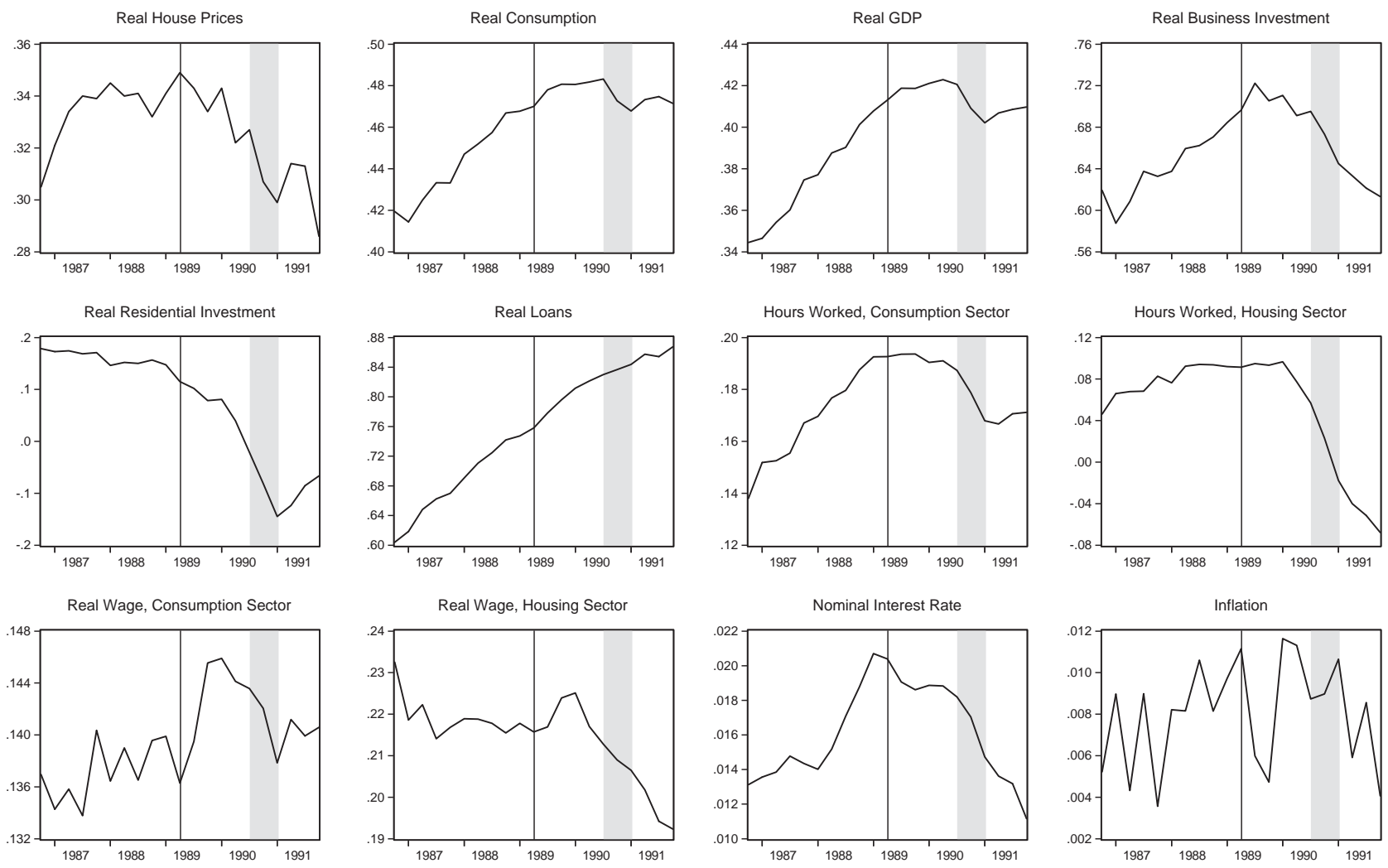

Figure 6: 1989:2 Peak
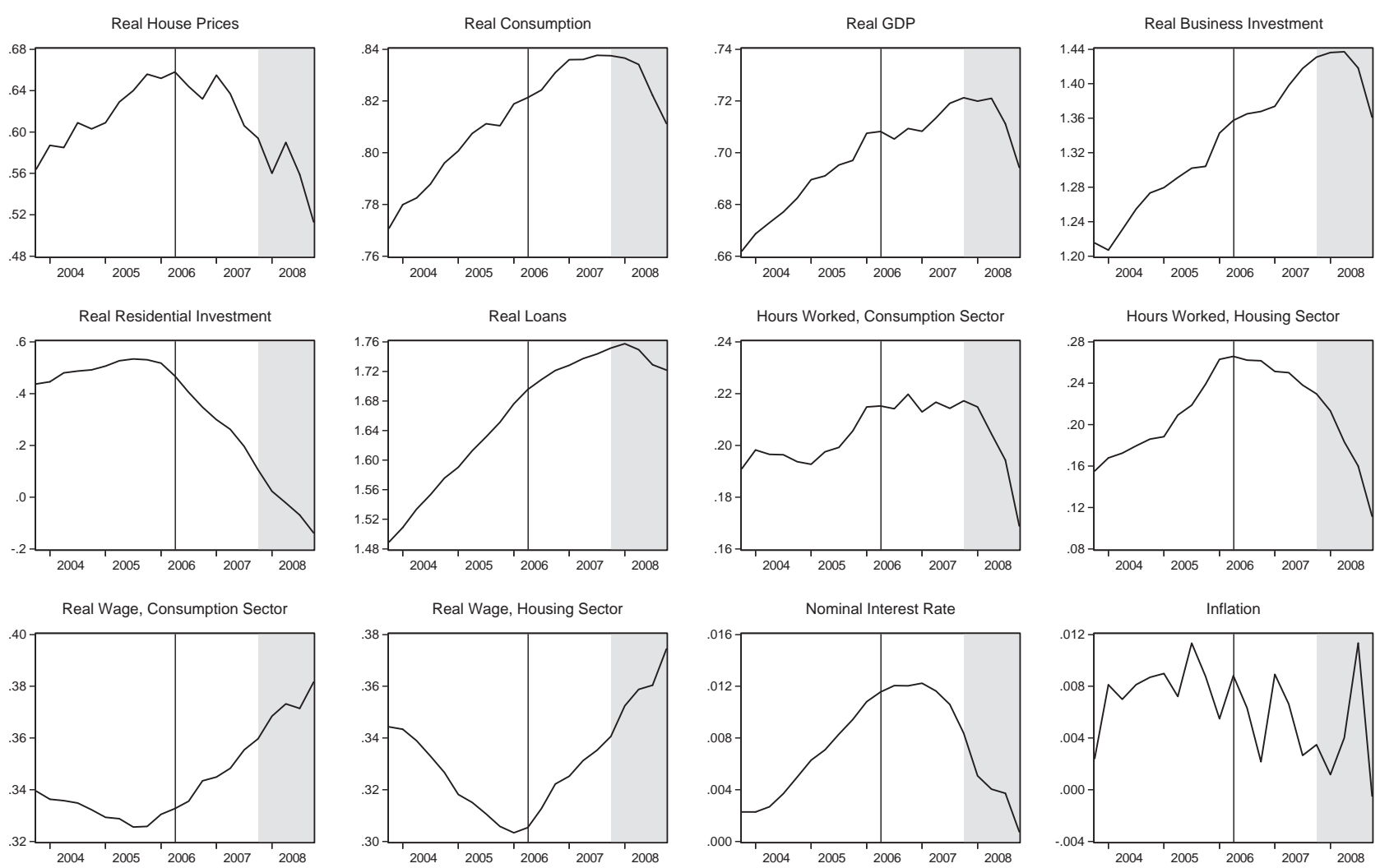

Figure 7: 2006:2 Peak 

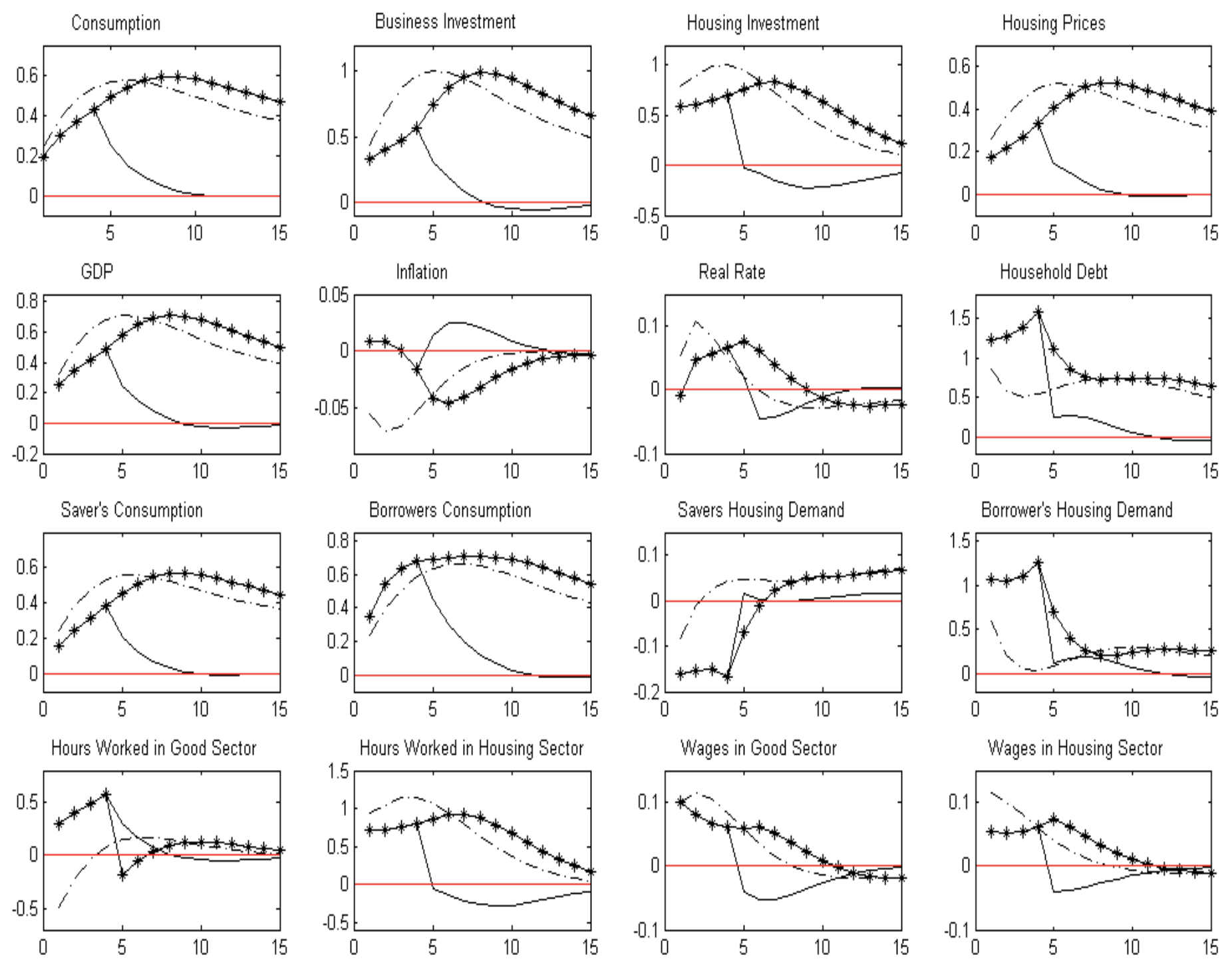

---・Current Shock —-Anticipated Shock — Not Realized Shock 

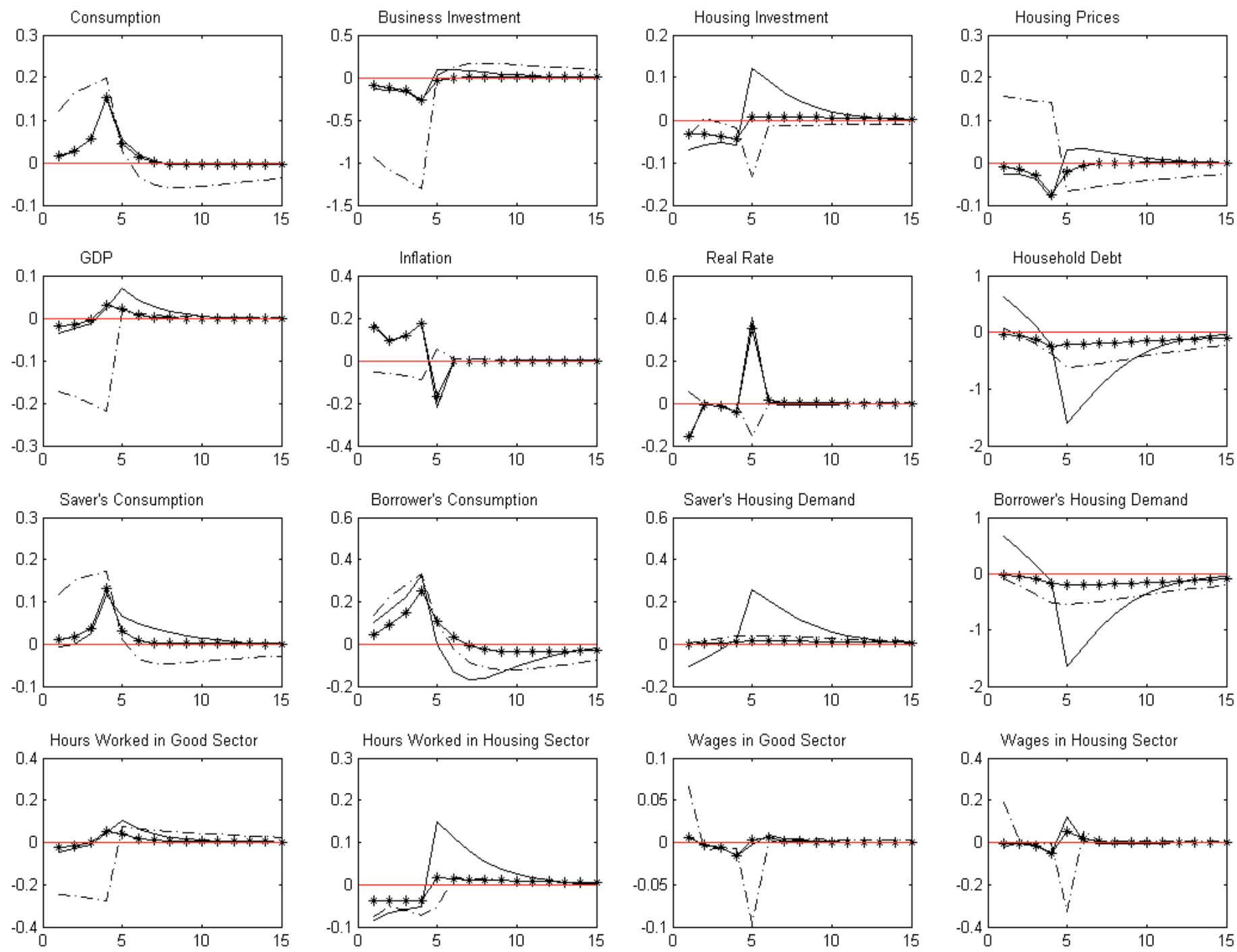

$-\cdot-\cdots$ No Adjustment Costs and No Collateral Effect — * Adjustment Costs and No Collateral Effect —— Adjustment Costs and Collateral Effect 

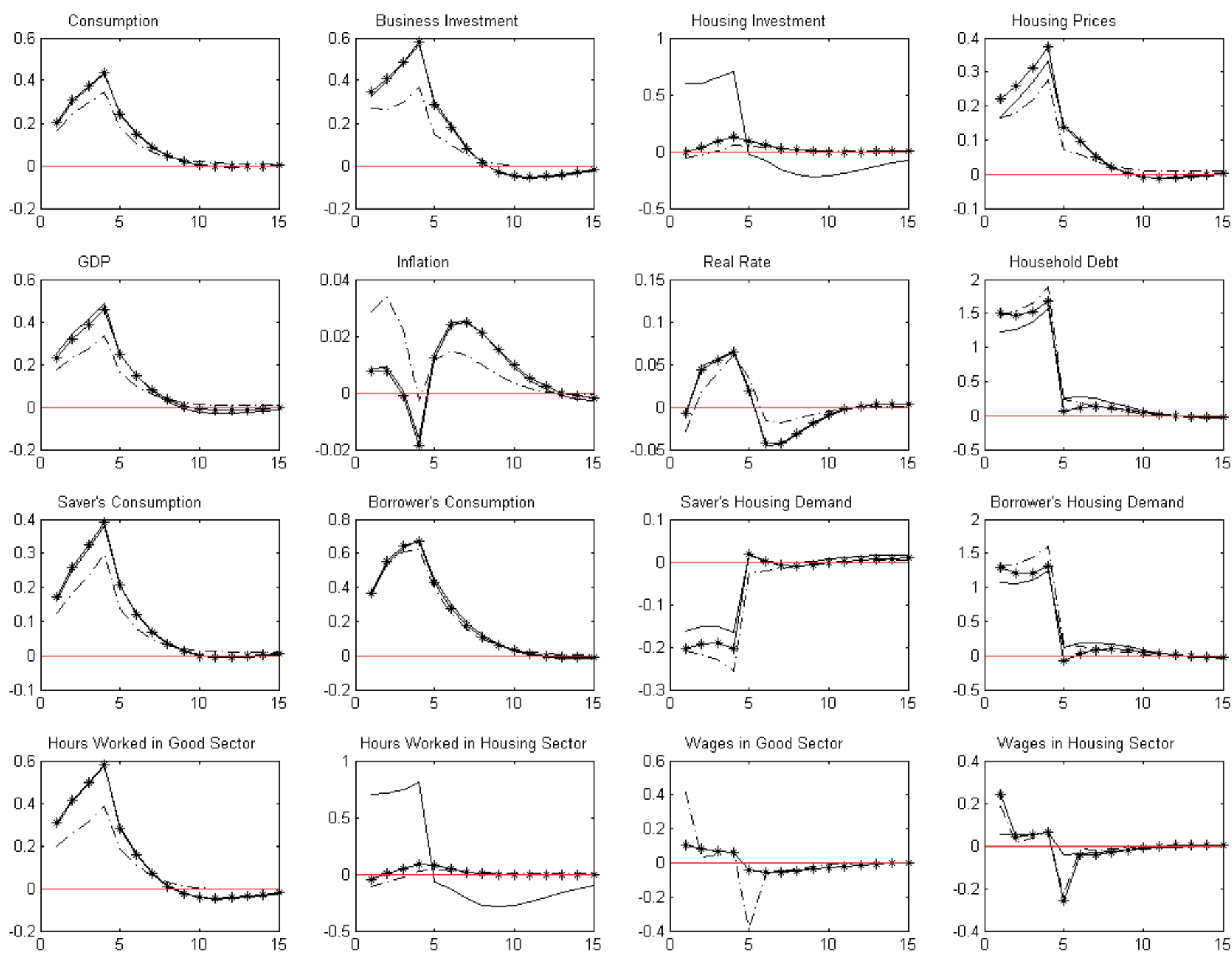

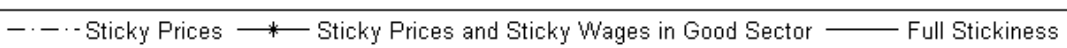



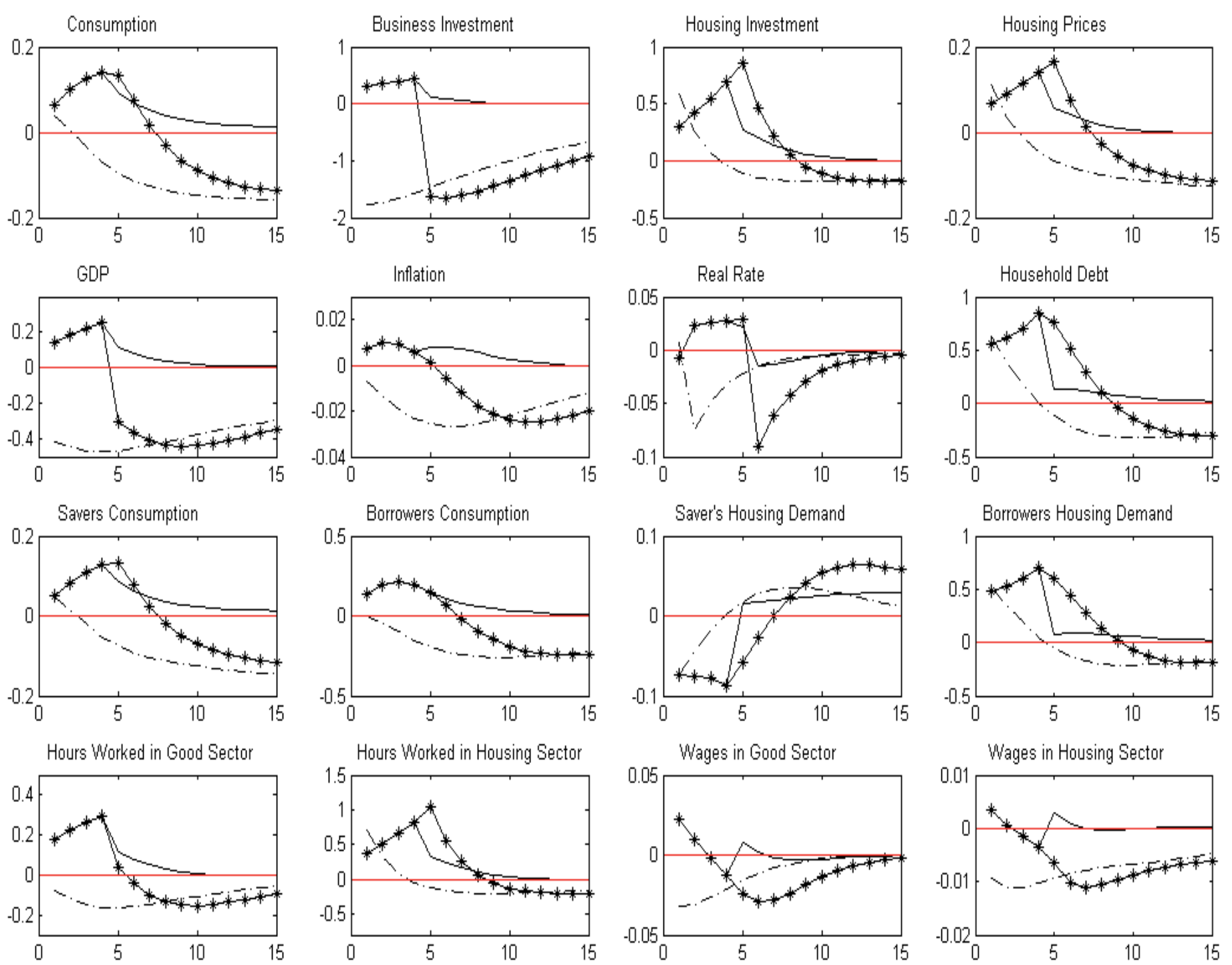

- - - Current Shock — Anticipated Shock — Not Realized Shock

Figure 11: News on Investment-Specific Technology Shock 

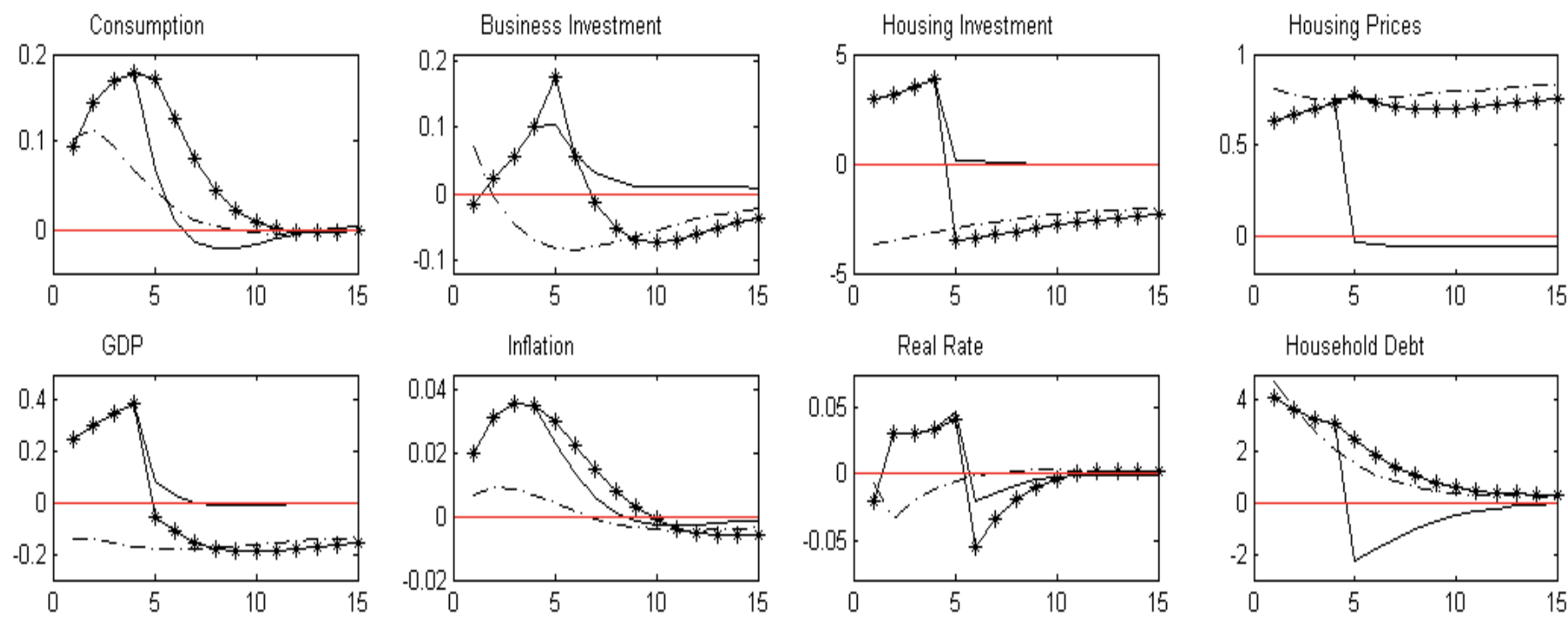

Household Debt
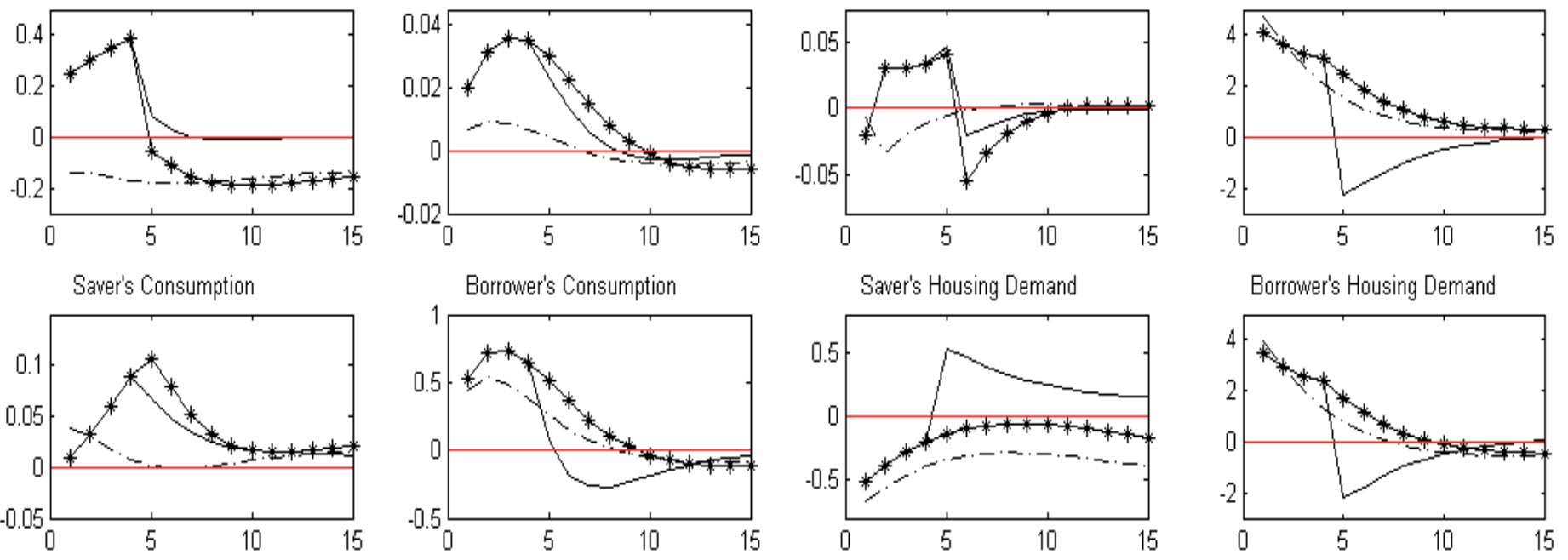

Borrower's Housing Demand
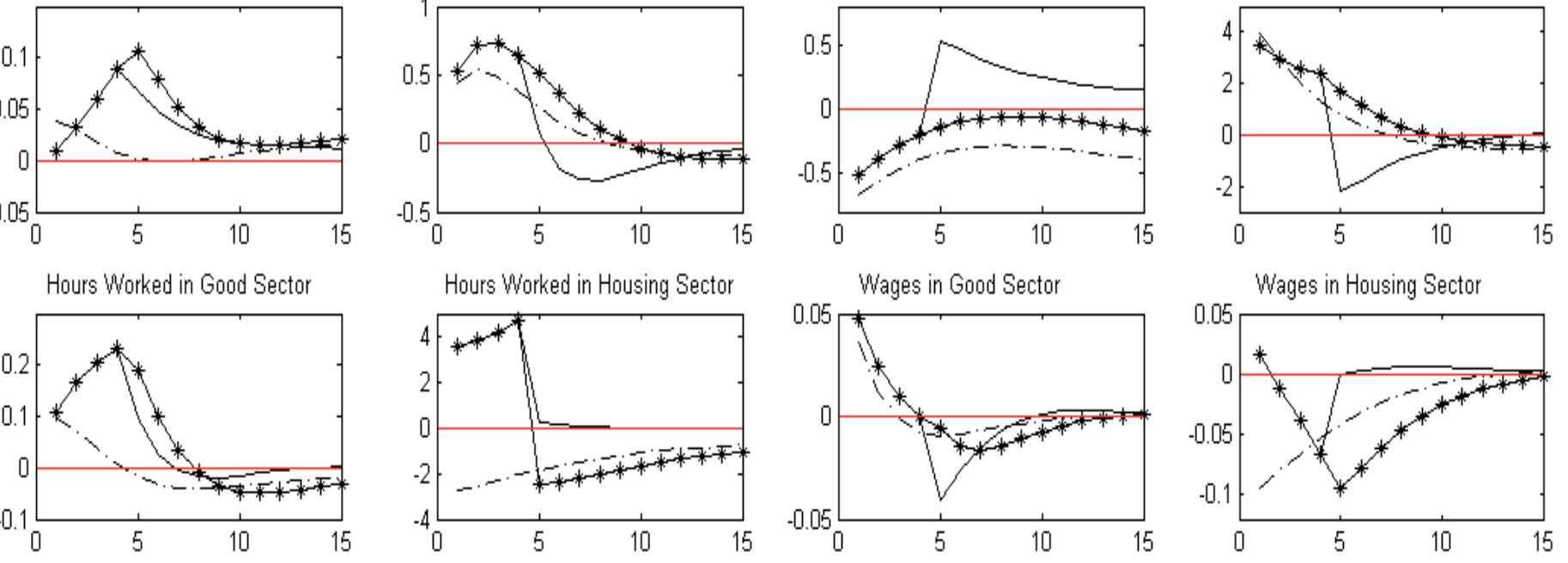

-.-. Current Shock — Anticipated Shock — Not Realized Shock

Figure 12: News on Housing Technology Shock 

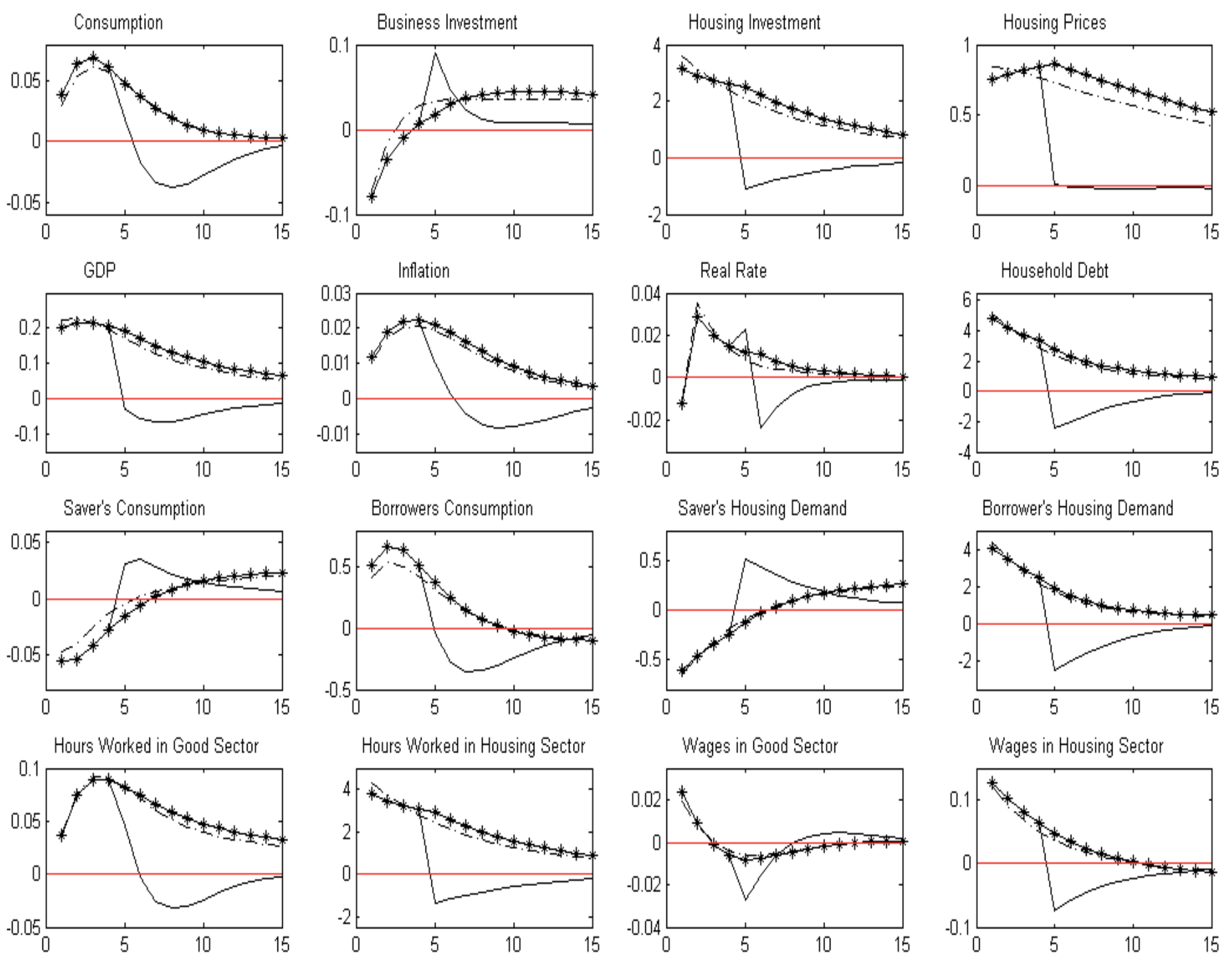

-.--C Current Shock — Anticipated Shock — Not Realized Shock

Figure 13: News on Housing Demand Shock 



Figure 14: News on Housing Demand Shock - Lags Impact 

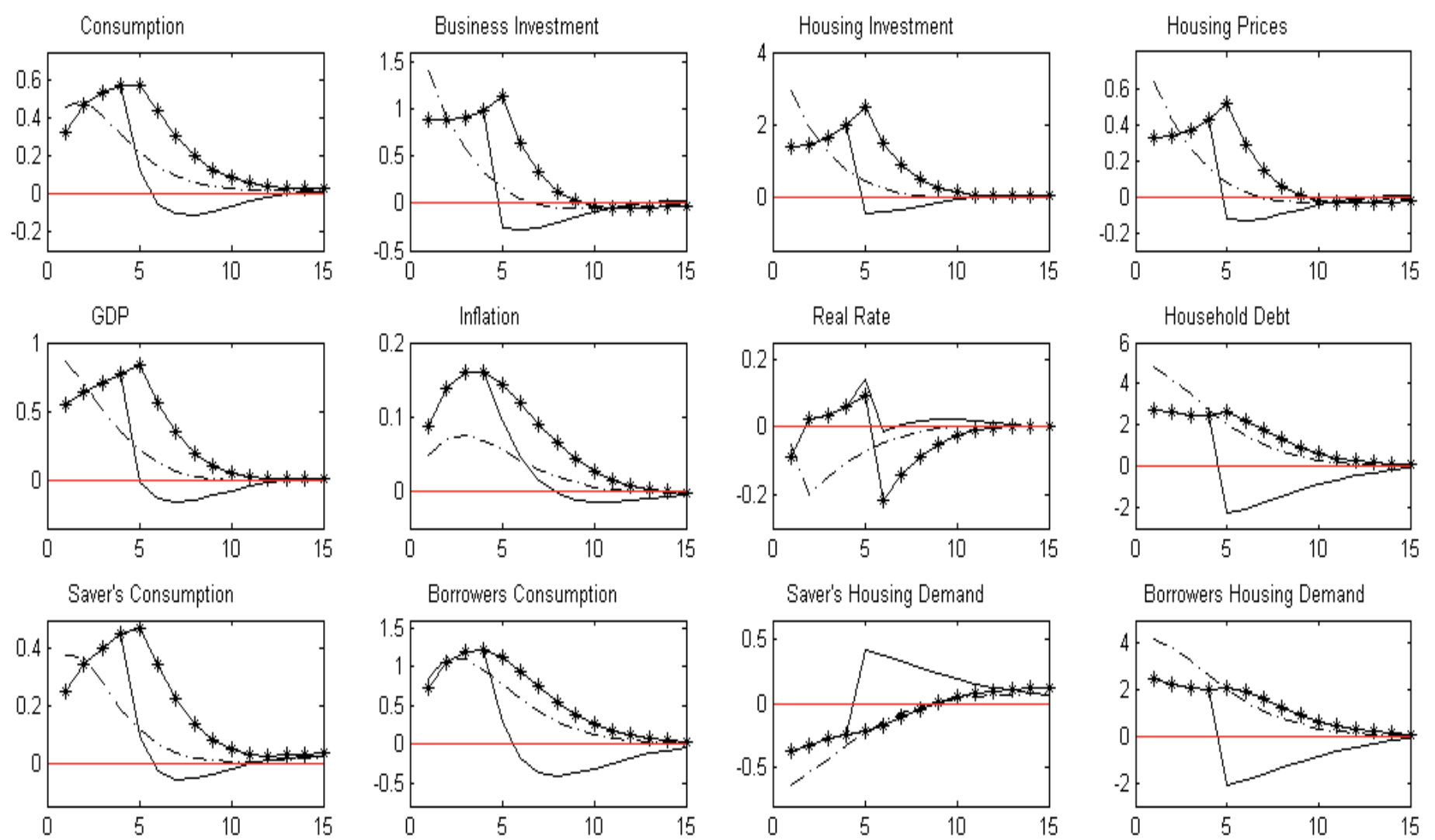

Borrowers Housing Demand

Hours Worked in Good Sector
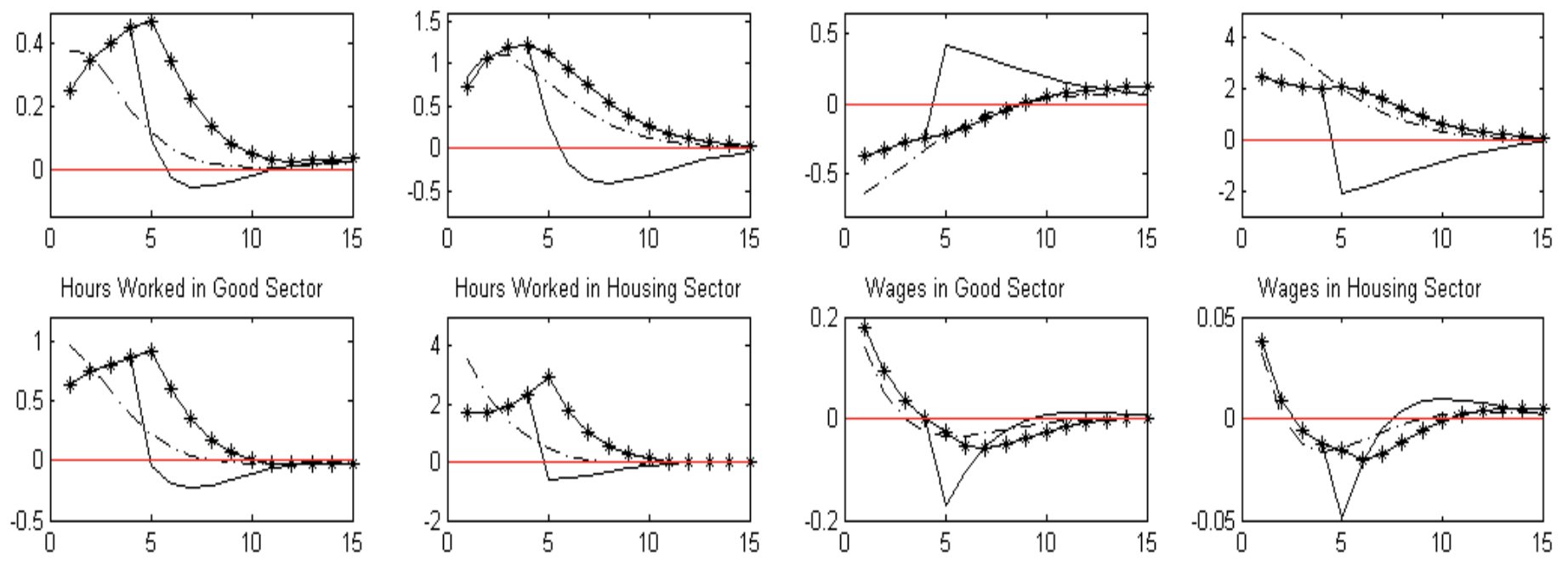

- - - Current Shock — Anticipated Shock — Not Realized Shock

Figure 15: News on Monetary Policy Shock 

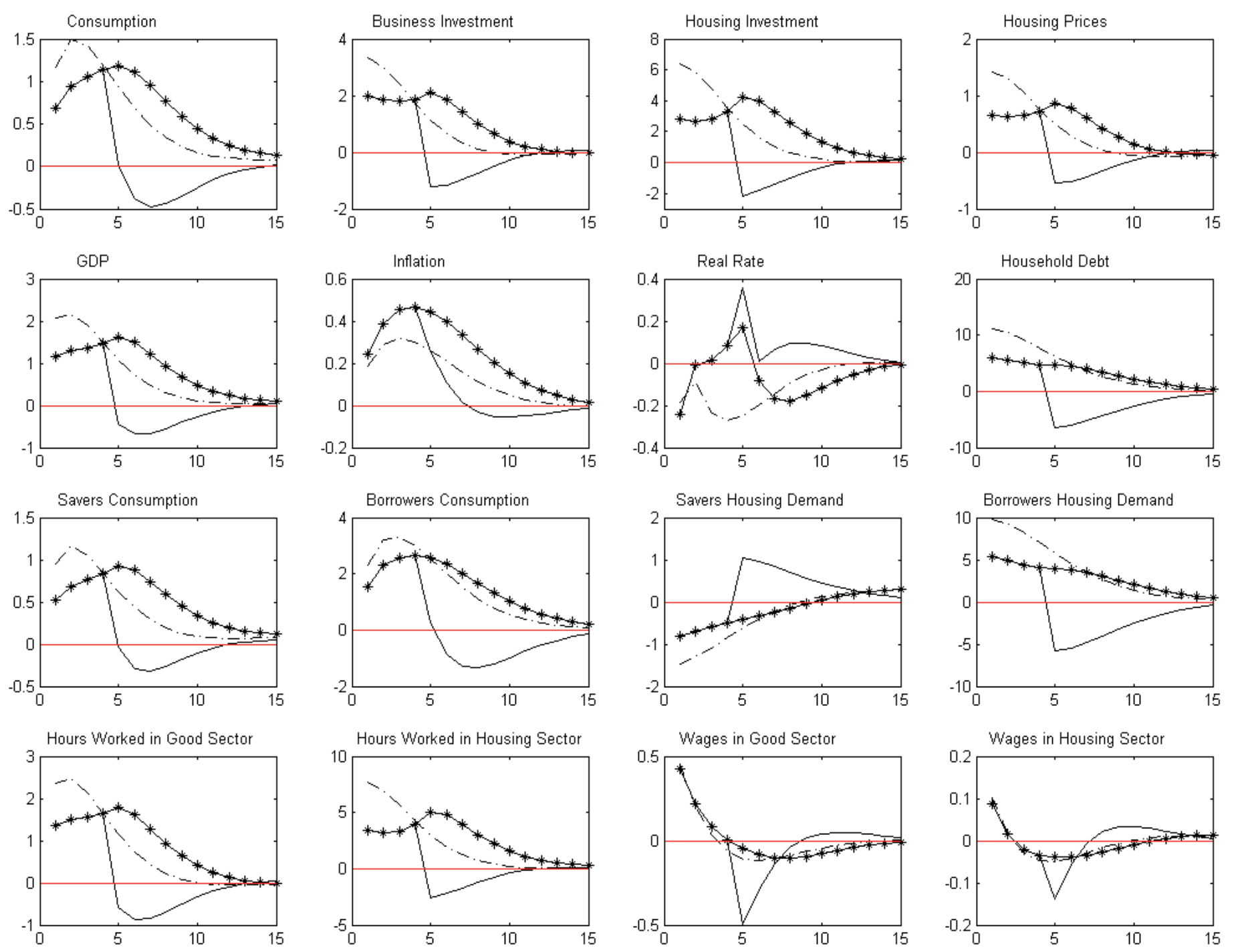

$-\cdot-\cdot$ Current Shock — * Anticipated Shock — Not Realized Shock 

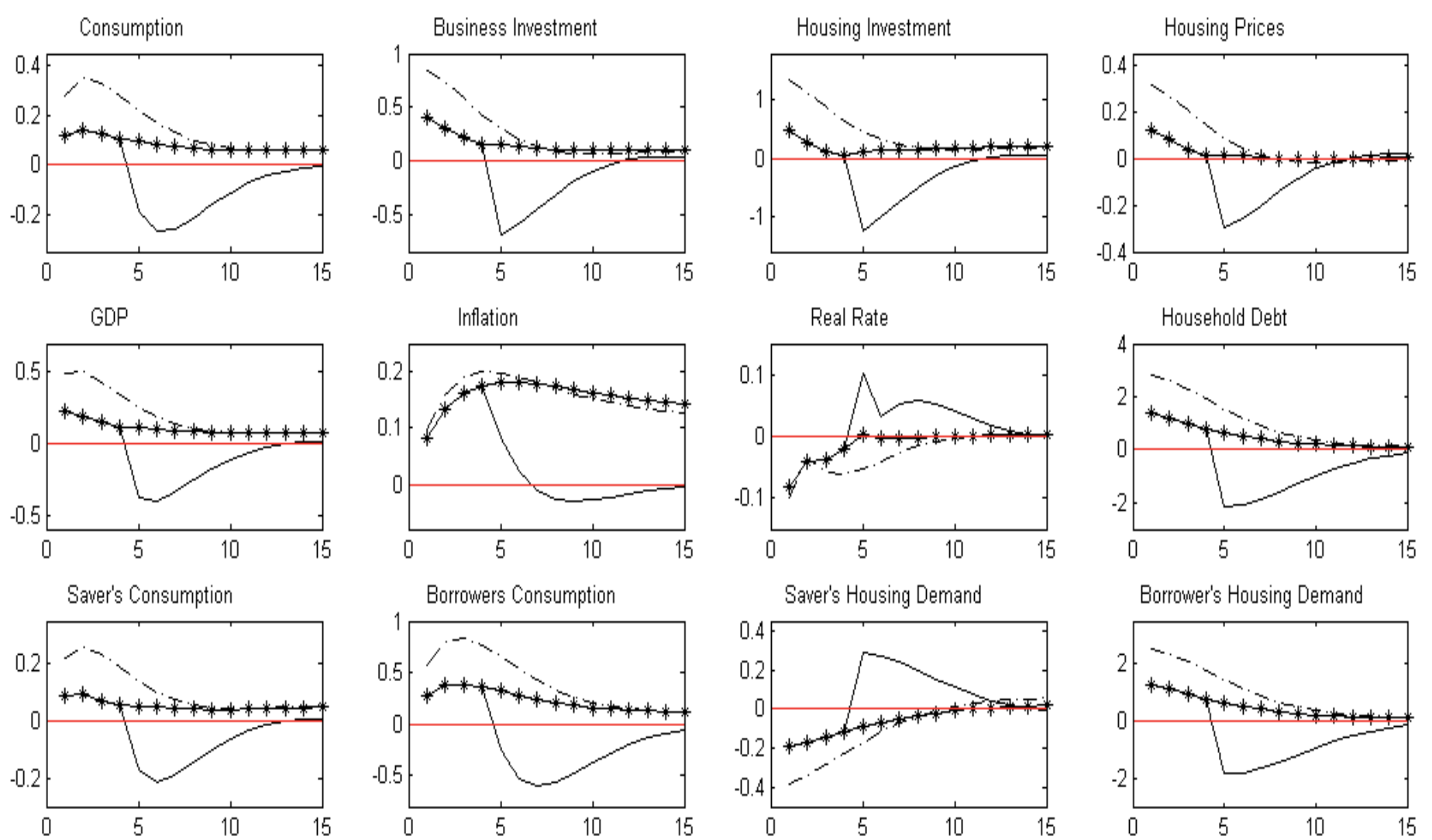

Borrower's Housing Demand

Hours Worked in Good Sector
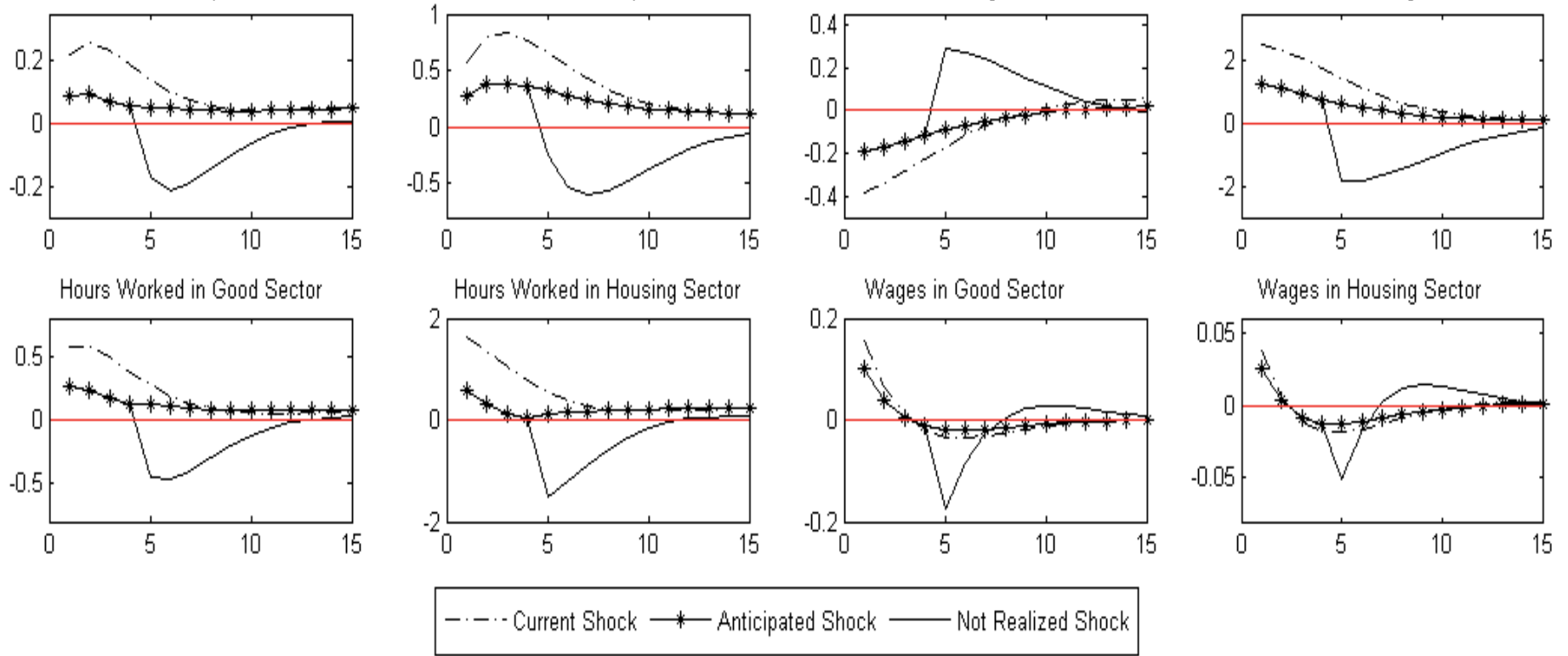

Figure 17: News on Central Bank's Inflation Target Shock 

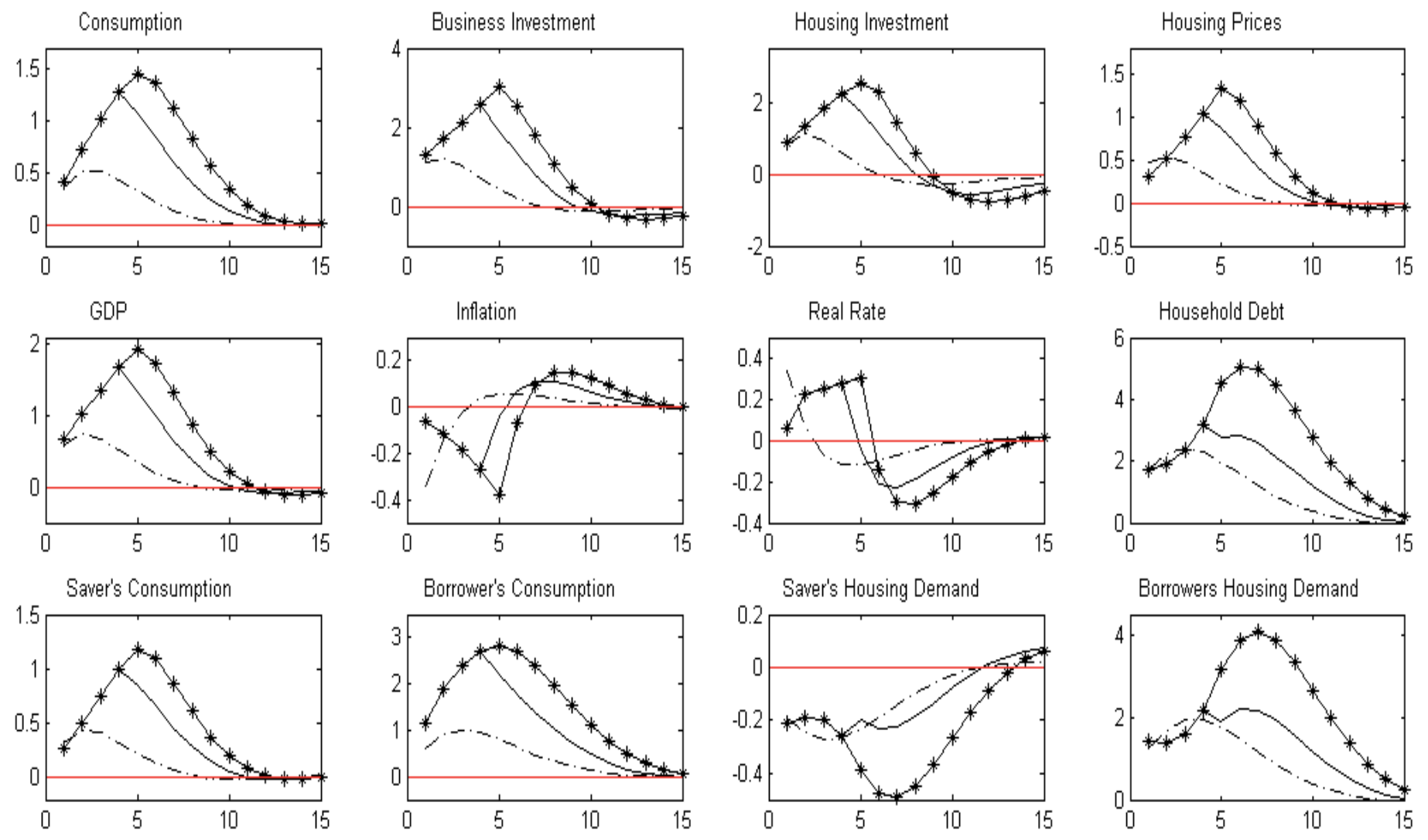

Borrowers Housing Demand

Hours Worked in Good Sector
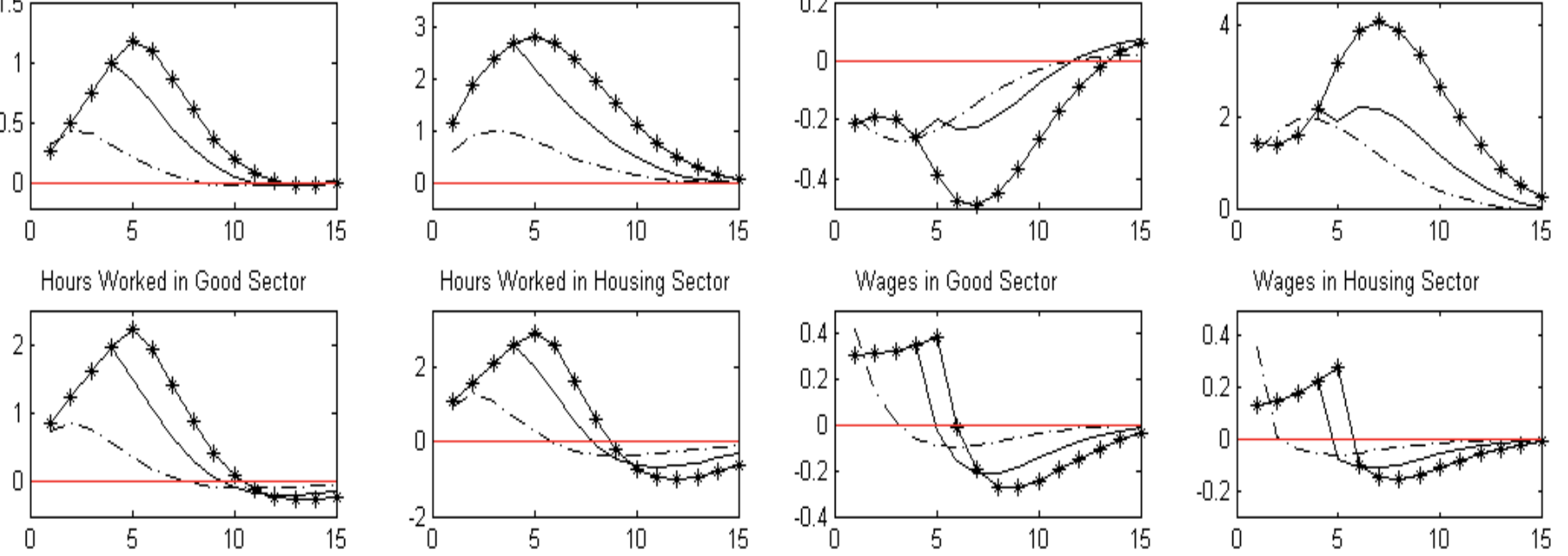

----Current Shock — Anticipated Shock — Not Realized Shock 

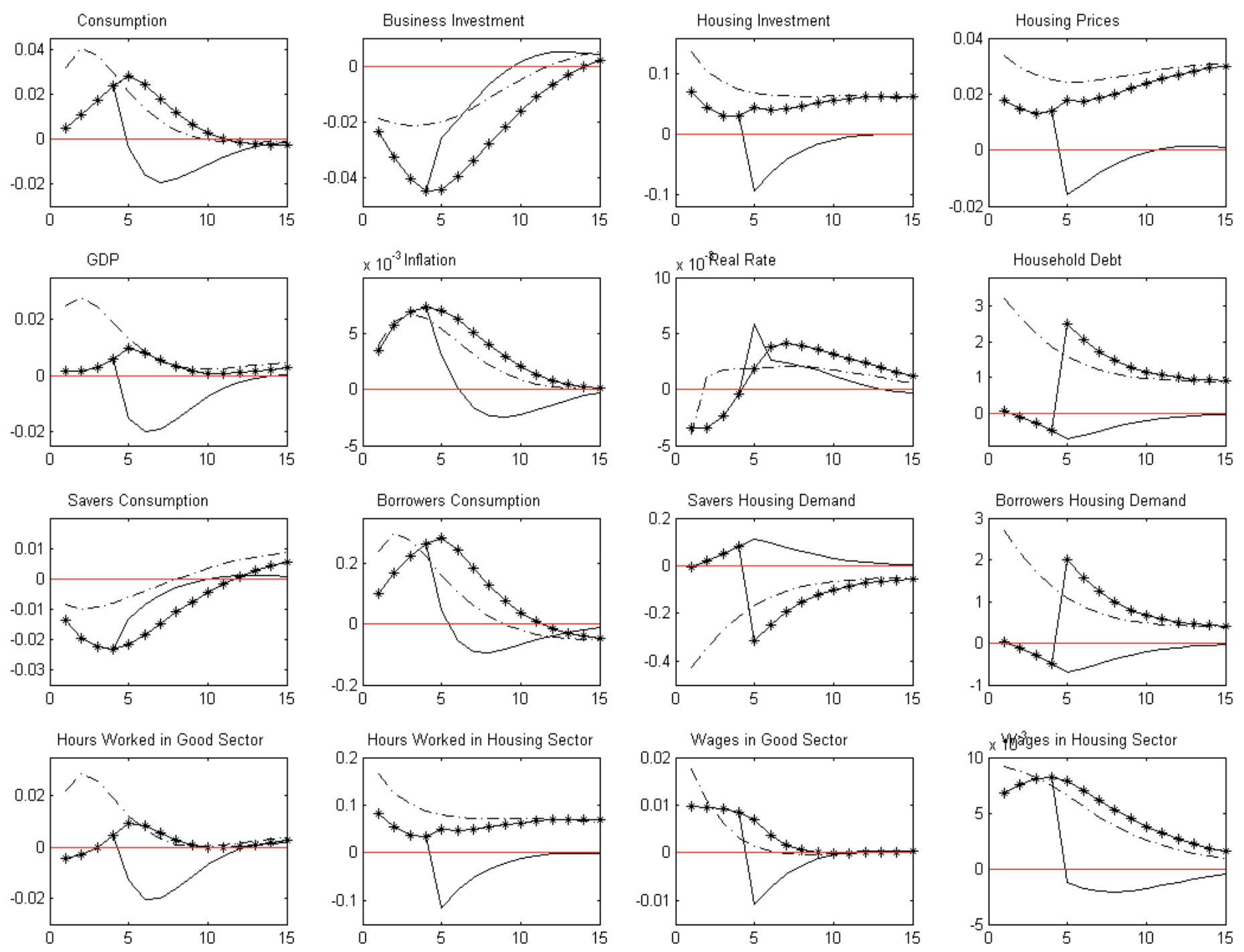

$-\cdot-\cdot$ Current Shock $\longrightarrow$ * Anticipated Shock $\longrightarrow$ Not realized Shock

Figure 19: News on Positive L-T-V Ratio Shock 

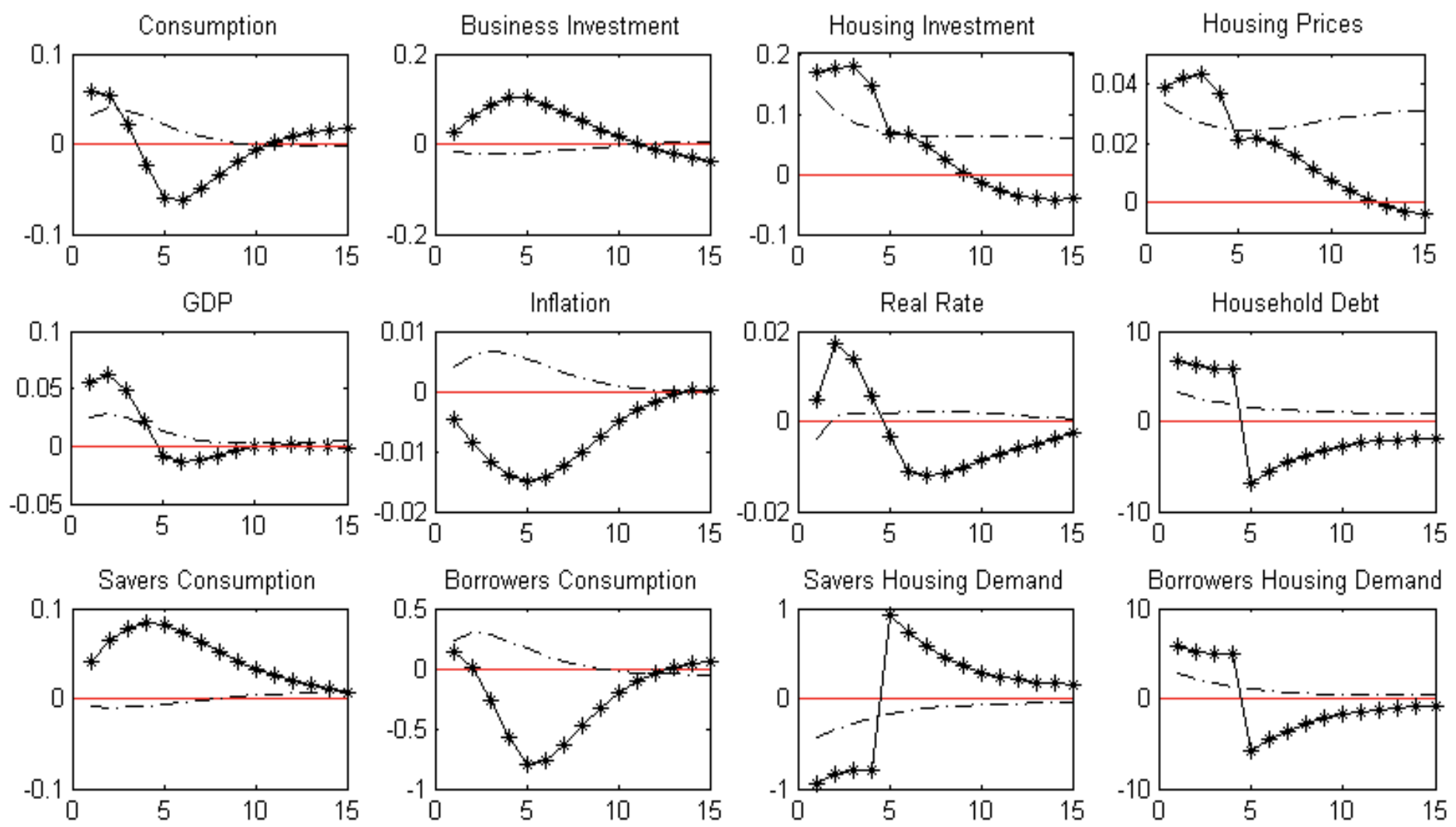

Borrowers Housing Demand
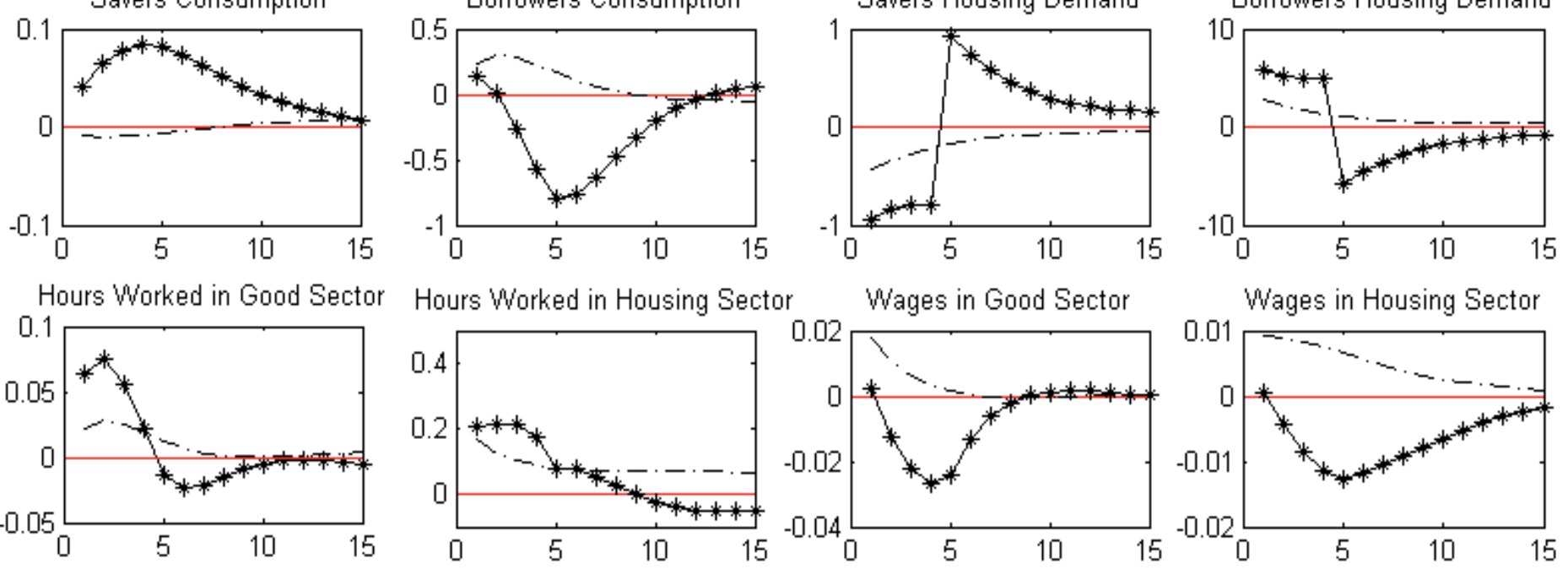

-.- - current shock —* current shock + future expected reversion 

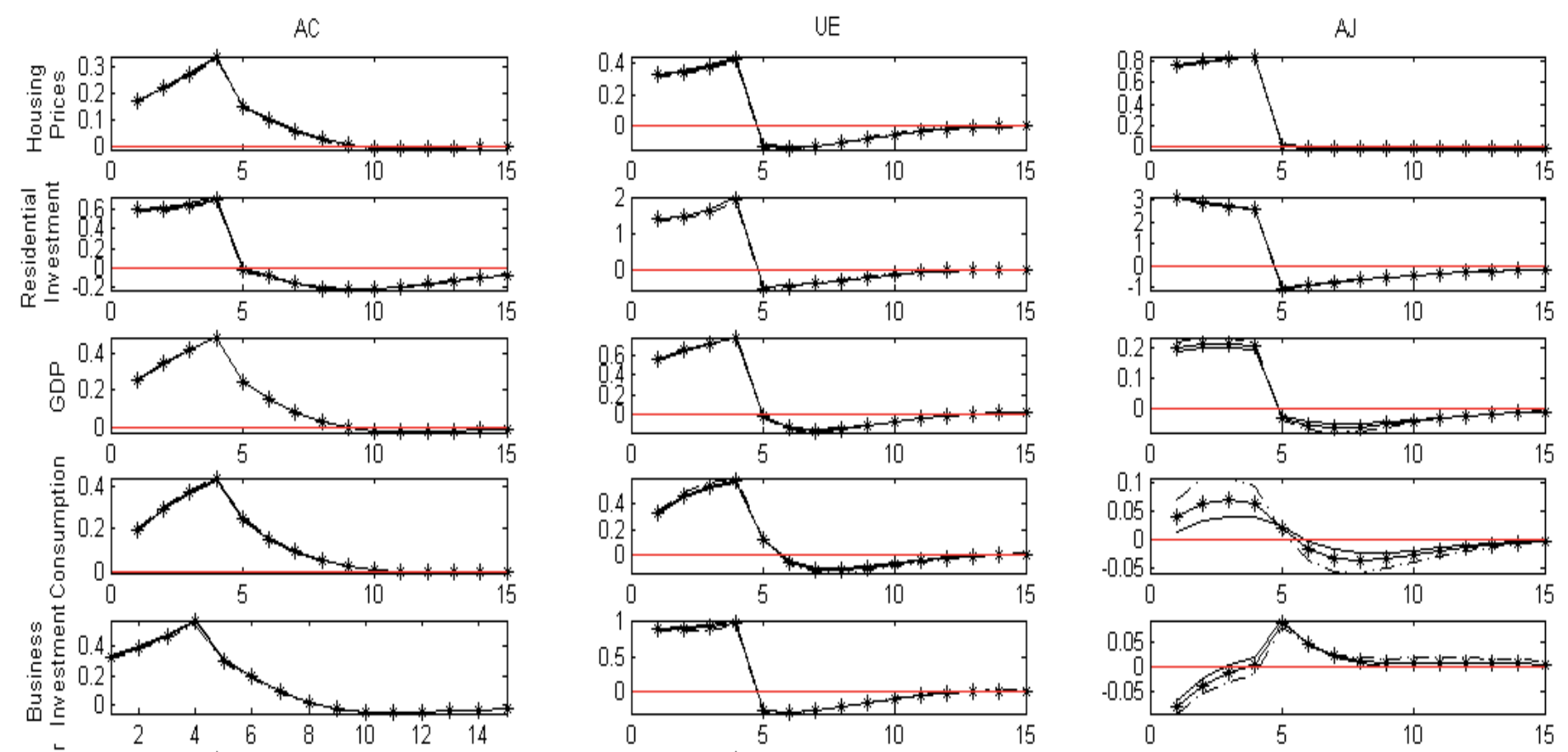

0.5
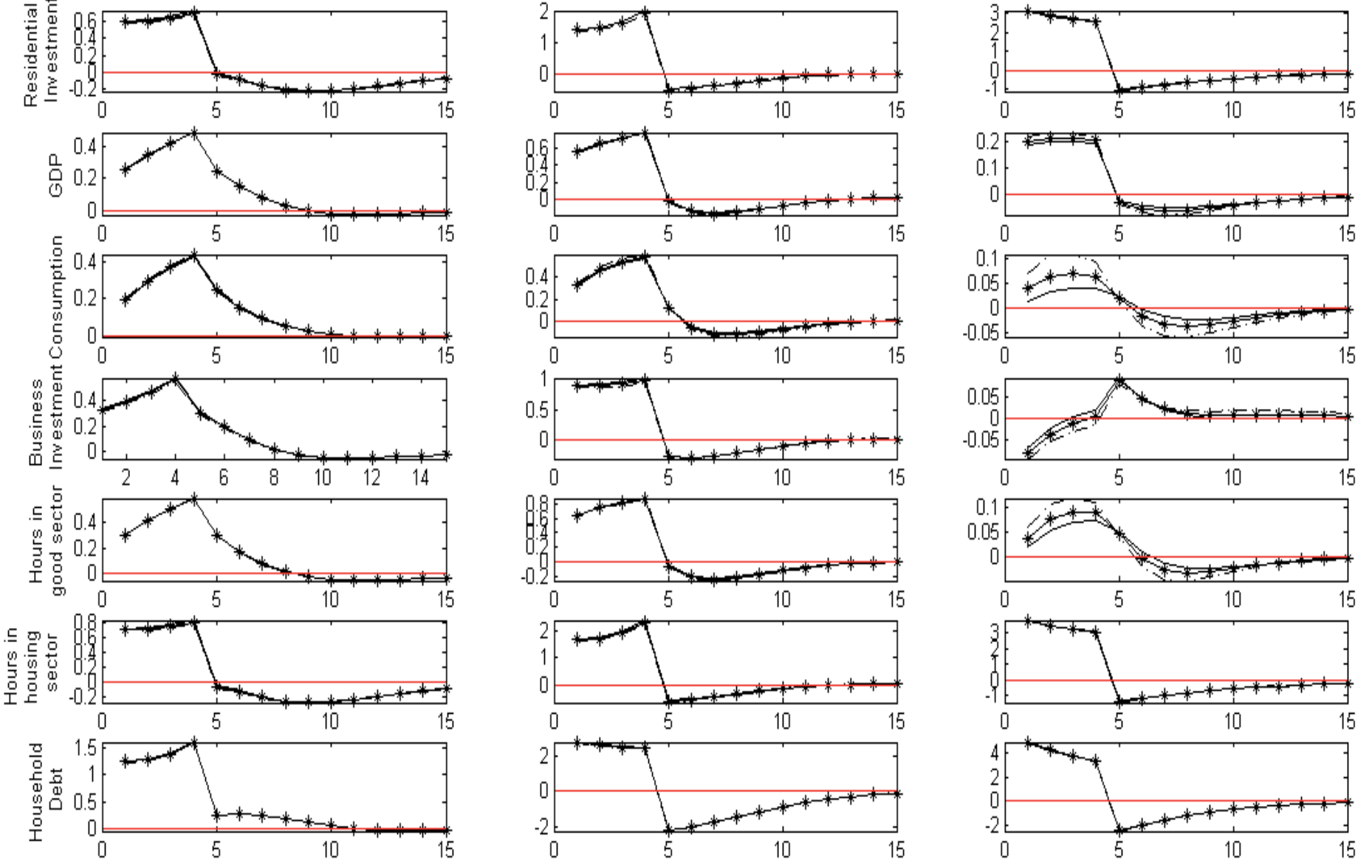

$$
\text { -.--. } \alpha=0.72 \longrightarrow \alpha=0.79 \longrightarrow \alpha=0.85
$$

Figure 21: Response to a 4-quarters-ahead expectations on technology (AC), the policy interest rate (UE) and the housing demand (AJ) that are not fulfilled respect to the share of lenders. 


\section{News Shocks}
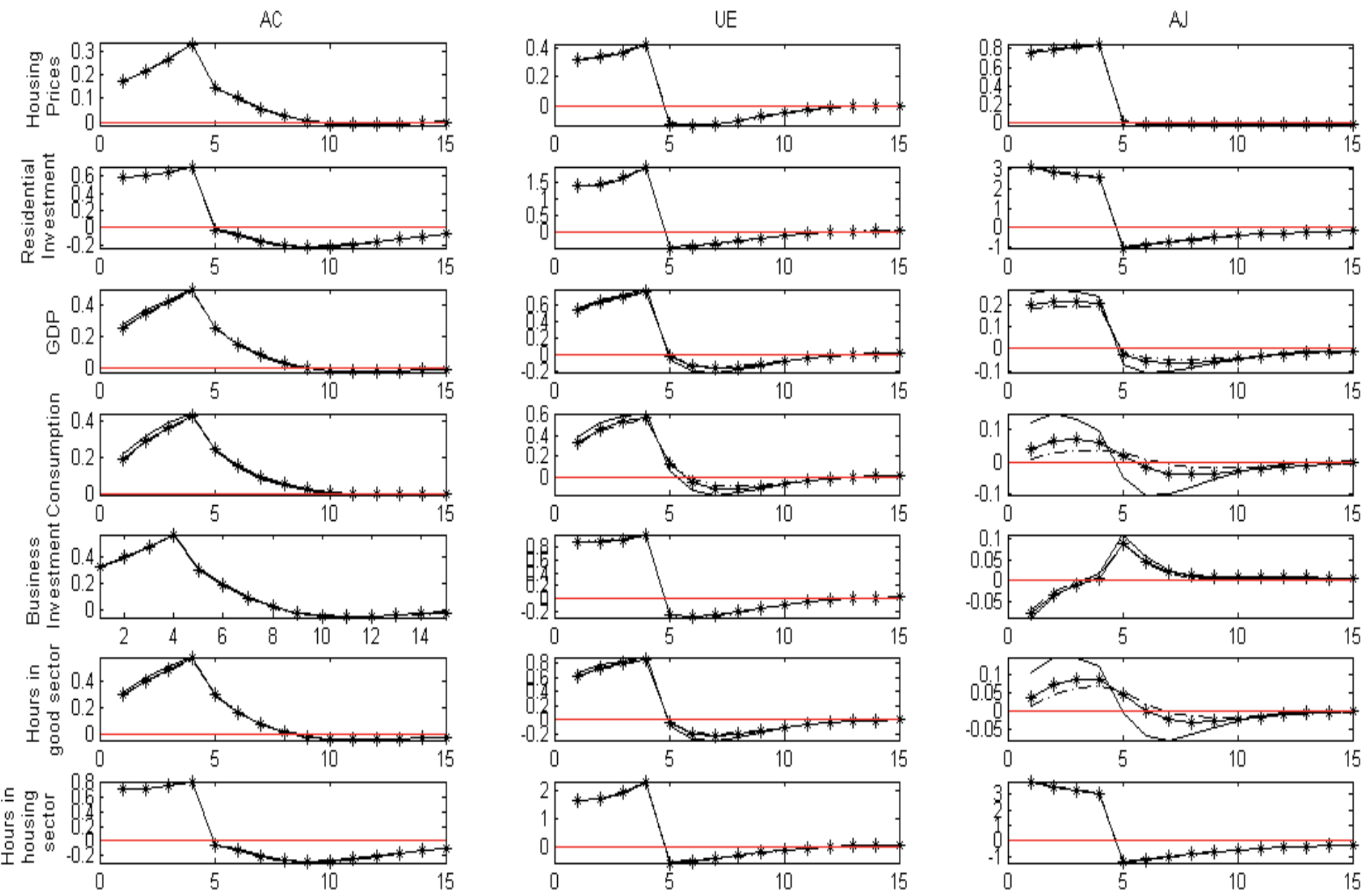

\section{5}
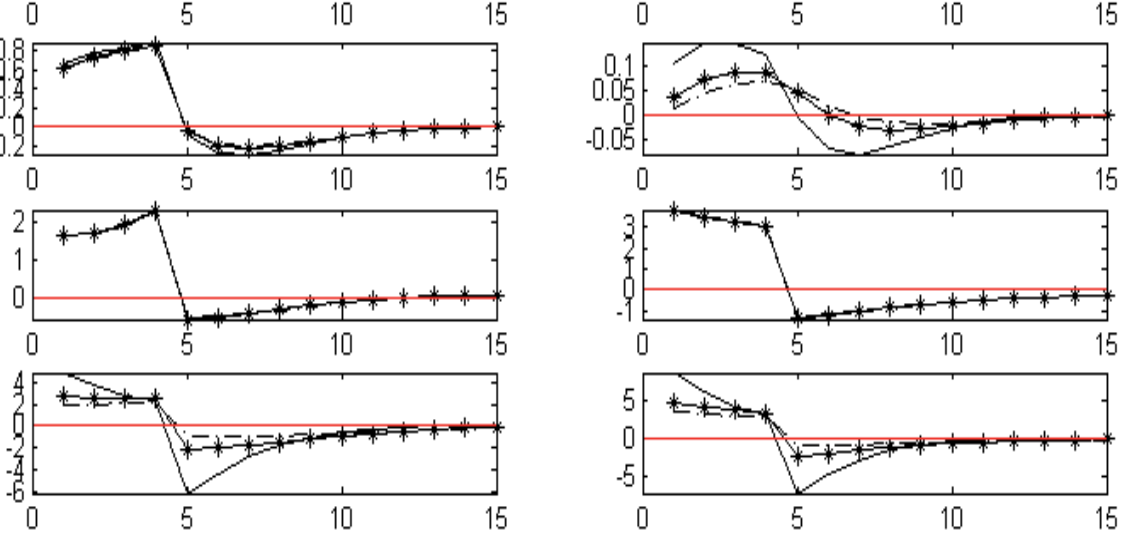

$-\cdot-\cdot-m=0.775 \longrightarrow m=0.85 \longrightarrow m=0.925$

Figure 22: Response to a 4-quarters-ahead expectations on technology ( $\mathrm{AC}$ ), the policy interest rate (UE) and the housing demand (AJ) that are not fulfilled respect to the L-T-V ratio. 


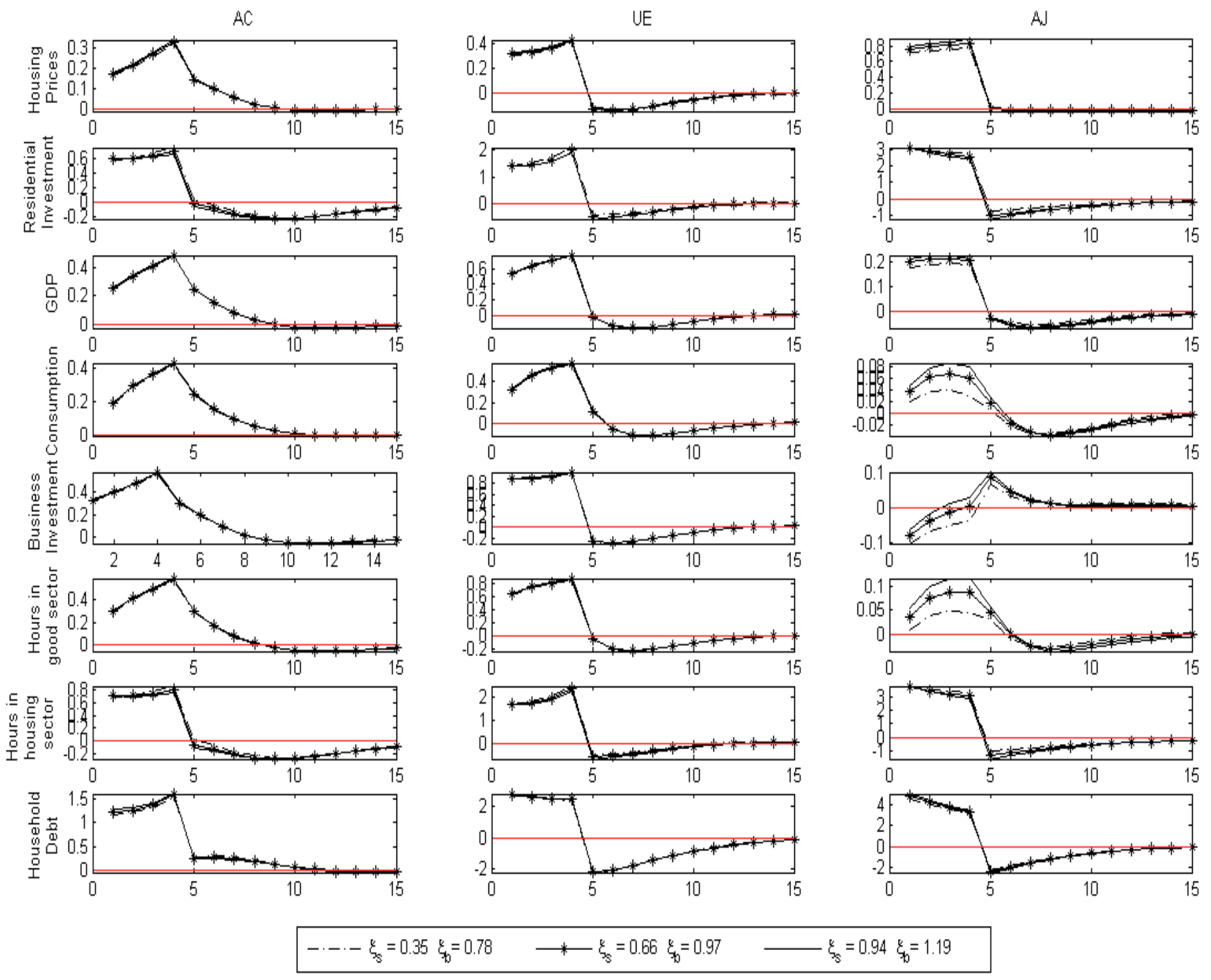

Figure 23: Response to a 4-quarters-ahead expectations on technology (AC), the policy interest rate (UE) and the housing demand (AJ) that are not fulfilled respect to the degree of labor mobility. 
News Shocks
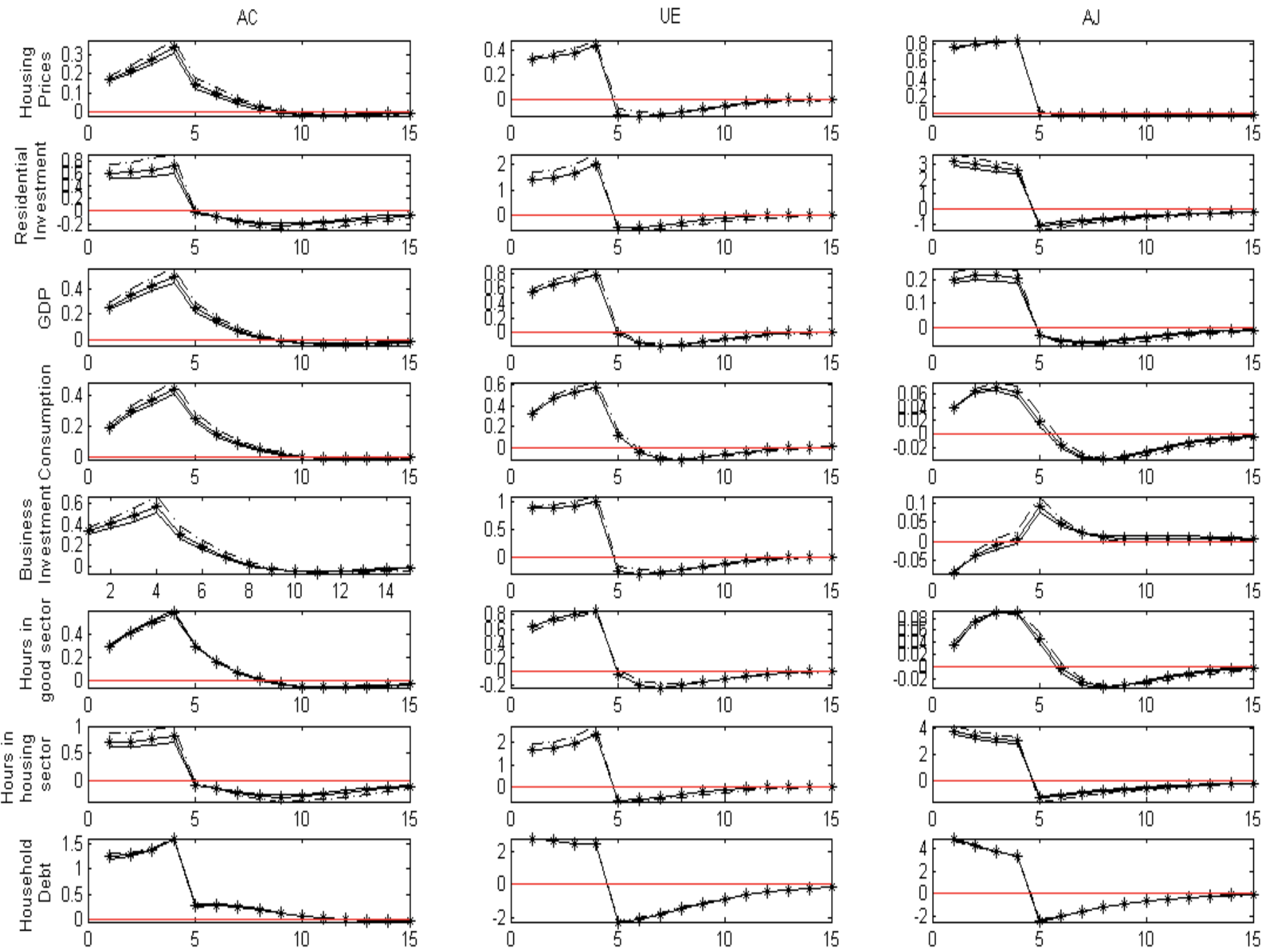

$$
-\cdot-\cdot-\cdots=0.46 \quad \zeta=0.69 \quad \zeta=0.87
$$

Figure 24: Response to a 4-quarters-ahead expectations on technology (AC), the policy interest rate (UE) and the housing demand (AJ) that are not fulfilled respect to the rate of capital utilization. 


\title{
BANCO DE ESPAÑA PUBLICATIONS
}

\author{
WORKING PAPERS
}

0901 PRAVEEN KUJAL AND JUAN RUIZ: International trade policy towards monopoly and oligopoly

0902 CATIA BATISTA, AITOR LACUESTA AND PEDRO VICENTE: Micro evidence of the brain gain hypothesis: The case of Cape Verde.

0903 MARGARITA RUBIO: Fixed and variable-rate mortgages, business cycles and monetary policy.

0904 MARIO IZQUIERDO, AITOR LACUESTA AND RAQUEL VEGAS: Assimilation of immigrants in Spain: A longitudinal analysis.

0905 ÁNGEL ESTRADA: The mark-ups in the Spanish economy: international comparison and recent evolution.

0906 RICARDO GIMENO AND JOSÉ MANUEL MARQUÉS: Extraction of financial market expectations about inflation and interest rates from a liquid market.

0907 LAURA HOSPIDO: Job changes and individual-job specific wage dynamics.

0908 M. ${ }^{a}$ DE LOS LLANOS MATEA AND JUAN S. MORA-SANGUINETTI: Developments in retail trade regulation in Spain and their macroeconomic implications. (The original Spanish version has the same number.)

0909 JAVIER MENCÍA AND ENRIQUE SENTANA: Multivariate location-scale mixtures of normals and mean-varianceskewness portfolio allocation.

0910 ALICIA GARCÍA-HERRERO, SERGIO GAVILÁ AND DANIEL SANTABÁRBARA: What explains the low profitability of Chinese banks?

0911 JAVIER MENCÍA: Assessing the risk-return trade-off in loans portfolios.

0912 MAXIMO CAMACHO AND GABRIEL PEREZ-QUIROS: Ñ-STING: España Short Term Indicator of Growth.

0913 RAQUEL VEGAS, ISABEL ARGIMÓN, MARTA BOTELLA AND CLARA I. GONZÁLEZ: Retirement behaviour and retirement incentives in Spain.

0914 FEDERICO CINGANO, MARCO LEONARDI, JULIÁN MESSINA AND GIOVANNI PICA: The effect of employment protection legislation and financial market imperfections on investment: Evidence from a firm-level panel of EU countries.

0915 JOSÉ MANUEL CAMPA AND IGNACIO HERNANDO: Cash, access to credit, and value creation in M\&As.

0916 MARGARITA RUBIO: Housing market heterogeneity in a monetary union.

0917 MAXIMO CAMACHO, GABRIEL PEREZ-QUIROS AND HUGO RODRÍGUEZ MENDIZÁBAL: High-growth Recoveries, Inventories and the Great Moderation.

0918 KAI CHRISTOFFEL, JAMES COSTAIN, GREGORY DE WALQUE, KEITH KUESTER, TOBIAS LINZERT, STEPHEN MILLARD AND OLIVIER PIERRARD: Wage, inflation and employment dynamics with labour market matching.

0919 JESÚS VÁZQUEZ, RAMÓN MARÍA-DOLORES AND JUAN-MIGUEL LONDOÑO: On the informational role of term structure in the U.S. monetary policy rule.

0920 PALOMA LÓPEZ-GARCÍA AND SERGIO PUENTE: What makes a high-growth firm? A probit analysis using Spanish firm-level data.

0921 FABIO CANOVA, MATTEO CICCARELLI AND EVA ORTEGA: Do institutional changes affect business cycles? Evidence from Europe.

0922 GALO NUÑO: Technology, convergence and business cycles.

0923 FRANCISCO DE CASTRO AND JOSÉ LUIS FERNÁNDEZ: The relationship between public and private saving in Spain: does Ricardian equivalence hold?

0924 GONZALO FERNÁNDEZ-DE-CÓRDOBA, JAVIER J. PÉREZ AND JOSÉ L. TORRES: Public and private sector wages interactions in a general equilibrium model.

0925 ÁNGEL ESTRADA AND JOSÉ MANUEL MONTERO: R\&D investment and endogenous growth: a SVAR approach.

0926 JUANA ALEDO, FERNANDO GARCÍA-MARTÍNEZ AND JUAN M. MARÍN DIAZARAQUE: Firm-specific factors influencing the selection of accounting options provided by the IFRS: Empirical evidence from Spanish market.

0927 JAVIER ANDRÉS, SAMUEL HURTADO, EVA ORTEGA AND CARLOS THOMAS: Spain in the euro: a general equilibrium analysis.

0928 MAX GILLMAN AND ANTON NAKOV: Monetary effects on nominal oil prices.

0929 JAVIER MENCÍA AND ENRIQUE SENTANA: Distributional tests in multivariate dynamic models with Normal and Student $t$ innovations.

0930 JOAN PAREDES, PABLO BURRIEL, FRANCISCO DE CASTRO, DANIEL GARROTE, ESTHER GORDO AND JAVIER J. PÉREZ: Fiscal policy shocks in the euro area and the US: an empirical assessment.

1. Previously published Working Papers are listed in the Banco de España publications catalogue. 
0931 TERESA LEAL, DIEGO J. PEDREGAL AND JAVIER J. PÉREZ: Short-term monitoring of the Spanish Government balance with mixed-frequencies models.

0932 ANTON NAKOV AND GALO NUÑO: Oilgopoly: a general equilibrium model of the oil-macroeconomy nexus.

0933 TERESA LEAL AND JAVIER J. PÉREZ: Análisis de las desviaciones presupuestarias aplicado al caso del presupuesto del Estado.

0934 JAVIER J. PÉREZ AND A. JESÚS SÁNCHEZ: Is there a signalling role for public wages? Evidence for the euro area based on macro data.

0935 JOAN PAREDES, DIEGO J. PEDREGAL AND JAVIER J. PÉREZ: A quarterly fiscal database for the euro area based on intra-annual fiscal information.

1001 JAVIER ANDRÉS, ÓSCAR ARCE AND CARLOS THOMAS: Banking competition, collateral constraints and optimal monetary policy.

1002 CRISTINA BARCELÓ AND ERNESTO VILLANUEVA: The response of household wealth to the risk of losing the job: evidence from differences in firing costs.

1003 ALEXANDER KARAIVANOV, SONIA RUANO, JESÚS SAURINA AND ROBERT TOWNSEND: No bank, one bank, several banks: does it matter for investment?

1004 GABRIEL PEREZ-QUIROS AND HUGO RODRÍGUEZ MENDIZÁBAL: Asymmetric standing facilities: an unexploited monetary policy tool.

1005 GABRIEL JIMÉNEZ, JOSE A. LOPEZ AND JESÚS SAURINA: How does competition impact bank risk-taking?

1006 GIUSEPPE BERTOLA, AURELIJUS DABUSINSKAS, MARCO HOEBERICHTS, MARIO IZQUIERDO, CLAUDIA KWAPIL, JEREMI MONTORNĖS AND DANIEL RADOWSKI: Price, wage and employment response to shocks: evidence from the WDN Survey.

1007 JAVIER MENCÍA: Testing non-linear dependence in the Hedge Fund industry.

1008 ALFREDO MARTÍN-OLIVER: From proximity to distant banking: Spanish banks in the EMU.

1009 GALO NUÑO: Optimal research and development expenditure: a general equilibrium approach.

1010 LUIS J. ÁLVAREZ AND PABLO BURRIEL: Is a Calvo price setting model consistent with micro price data?

1011 JENS HAGENDORFF, IGNACIO HERNANDO, MARÍA J. NIETO AND LARRY D. WALL: What do premiums paid for bank M\&As reflect? The case of the European Union.

1012 DAVID DE ANTONIO LIEDO: General equilibrium restrictions for dynamic factor models.

1013 JAMES COSTAIN, JUAN F. JIMENO AND CARLOS THOMAS: Employment fluctuations in a dual labor market.

1014 LUIS M. VICEIRA Y RICARDO GIMENO: The euro as a reserve currency for global investors.

1015 PALOMA LÓPEZ-GARCÍA AND JOSÉ MANUEL MONTERO: Understanding the Spanish business innovation gap: The role of spillovers and firms' absorptive capacity.

1016 AITOR LACUESTA AND SERGIO PUENTE: El efecto del ciclo económico en las entradas y salidas de inmigrantes en España.

1017 REBEKKA CHRISTOPOULOU, JUAN F. JIMENO AND ANA LAMO: Changes in the wage structure in EU countries.

1018 THOMAS BREUER, MARTIN JANDAČKA, JAVIER MENCÍA AND MARTIN SUMMER: A systematic approach to multi-period stress testing of portfolio credit risk.

1019 LUIS J. ÁLVAREZ AND PABLO BURRIEL: Micro-based estimates of heterogeneous pricing rules: The United States vs. the euro area.

1020 ALFREDO MARTÍN-OLIVER AND VICENTE SALAS-FUMÁS: I.T. investment and intangibles: Evidence from banks.

1021 LUISA LAMBERTINI, CATERINA MENDICINO AND MARIA TERESA PUNZI: Expectations-driven cycles in the housing market.

BANCODEESPAÑA

Eurosistema
Unidad de Publicaciones Alcalá, 522; 28027 Madrid

Telephone +3491338 6363. Fax +34919986488

E-mail: publicaciones@bde.es www.bde.es 